\title{
Sulfur Derivatives of the Natural Polyarsenical Arsenicin A: Biologically Active, Organometallic Arsenic-Sulfur Cages Related to the Minerals Realgar and Uzonite
}

\author{
Di Lu, Sundaram Arulmozhiraja, Michelle L. Coote, A. David Rae, Geoff Salem,* Anthony C. Willis, \\ and S. Bruce Wild*
}

Research School of Chemistry, College of Physical Sciences, Australian National University, Canberra ACT 0200, Australia

Shirine Benhenda, Valerie Lallemand Breitenbach, and Hugues de Thé

University Paris Diderot, Sorbonne Paris Cité, Hôpital St Louis 1, Avenue Claude Vellefaux, Paris 75475 Cedex 10, France

Xiaoyi Zhai, Philip J. Hogg, and Pierre J. Dilda

Tumour Metabolism Group, Adult Cancer Program, Prince of Wales Clinical School and Lowy Cancer Research Centre, Faculty of Medicine, University of New South Wales, Sydney, NSW 2052, Australia

Supporting Information

ABSTRACT: ( \pm )-Arsenicin A (AsA), ( \pm )-1, the first natural polyarsenical to be isolated, has the adamantane-type structure of the mineral arsenolite $\left(\mathrm{As}_{4} \mathrm{O}_{6}\right)$, in which three of the oxygen atoms have been replaced by methylene groups to give an organometallic, arsenicoxygen cage of $C_{2}$ symmetry. Heating of a benzene solution of AsA with aqueous sodium sulfide produces, by reductive desulfurization of the intermediate sulfur analog $( \pm)-2$, the monosulfide cage $( \pm)-4$, which contains two As-As bonds and which has a $C_{2}$-chiral cage structure related to the mineral realgar $\left(\alpha-\mathrm{As}_{4} \mathrm{~S}_{4}\right)$. At room temperature the reaction affords a chiral disulfide derivative that exists as a pair of separable diastereomers, $( \pm)-3 \mathbf{a}$ and $( \pm)-3 \mathbf{b}$, each of which contains a single As-As bond and is structurally related to the mineral uzonite $\left(\mathrm{As}_{4} \mathrm{~S}_{5}\right)$. The crystal structures of the monosulfide $( \pm)-4$ and the

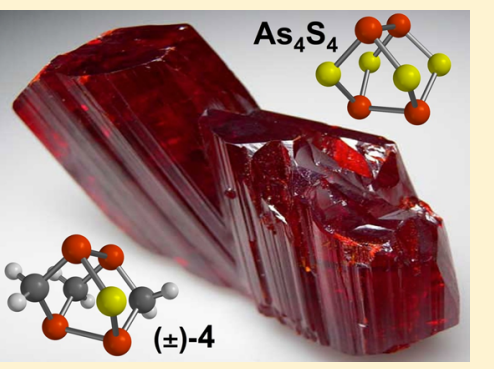
diastereomeric disulfides $( \pm)-3 a$ and $( \pm)-3 b$ have been determined. As for AsA, the sulfur derivatives exhibit strong UV absorptions and can be resolved on a Chiralpak IA column. The monosulfur cage $( \pm)-4$ is considerably more potent and more selective than AsA and the current "arsenical gold standard", arsenic(III) oxide as Trisenox, against the acute promelocytic leukemia cells (NB4) and certain solid cancer cell lines.

\section{INTRODUCTION}

The polyarsenical $( \pm)$-Arsenicin A (AsA), ( \pm )-1, was isolated in 2006 in trace amounts from the New Caledonian sponge Echinochalina bargibanti and was found to have potent bactericidal and fungicidal activities on human pathogenic strains. ${ }^{1}$ An X-ray structure determination on a crystal of synthetic $( \pm)-1$ confirmed that the molecule had the adamantane-type structure of the mineral arsenolite $\left(\mathrm{As}_{4} \mathrm{O}_{6}\right)$, in which three of the oxygen atoms had been replaced by methylene groups. ${ }^{2}$ This cage structure had been assigned to $( \pm)-1$ on the basis of detailed spectroscopic measurements and theoretical calculations. $^{3-5}$ A great variety of chiral marine arsenicals are known that contain a single arsenic atom, but these owe their chirality to an organic substituent, frequently the $\beta$-ribosyl group. ${ }^{6,7}$ The tetaarsenical $( \pm)-1$ is the first natural arsenical to be isolated that contains a chiral arsenic stereocenter. The formal substitution of three oxygen atoms by methylene groups in the $\mathrm{As}_{4} \mathrm{O}_{6}$ cage confers upon the otherwise insoluble mineral an organic solubility that renders it amenable to characterization and derivatization by typical organic techniques. An interesting property of $( \pm)-\mathbf{1}$ is the exhibition of an UV/vis spectrum in dichloromethane, even though the molecule contains no obvious chromaphore. A theoretical investigation revealed that the UV absorption was facilitated by through-space and through-bond interactions between lone pairs on the arsenic and oxygen atoms and the organometallic framework of the molecule. 8 The electronic absorption at $254 \mathrm{~nm}$ facilitated the resolution of $( \pm)-1$ by preparative HPLC on a Chiralpak IA column with $>99 \%$ efficiency; the absolute configuration of the $(-)_{589}$-enantiomer was established as overall $S$ by an X-ray crystal structure determination. ${ }^{9}$ Each enantiomer of $( \pm)-1$ contains four chiral stereocenters of the same configuration. The enantiomers of $( \pm)-1$ are configurationally stable in dichloromethane containing a trace of triethylamine but are sensitive to acid-catalyzed

Received: August 28, 2014

Published: February 11, 2015 
racemization by a mechanism that is considered to involve the inversion of aquated arsenium ions. ${ }^{9}$ It is noteworthy that the yeast Scopulariopsis brevicaulis, when growing on bread treated with aqueous ethyl( $n$-propyl)arsinic acid, synthesizes As-chiral $(S)$-ethylmethyl( $n$-propyl)arsine by reductive methylation with $60 \%$ enantioselectivity. ${ }^{10}$ Nevertheless, $( \pm)-1$ is the first natural arsenical to be isolated that contains a chiral arsenic stereocenter. The discovery of the remarkable efficacy of arsenic(III) oxide (as Trisenox) for the treatment of acute promelocytic leukemia (APL) has prompted investigations into the efficacy of a variety of inorganic and organic arsenicals for the treatment of other cancers. ${ }^{11}$ In a recent investigation, we demonstrated that $( \pm)-1$ exhibits a 21 -fold greater inhibition of the induction of proliferation arrest and induces cell death at a 27-fold lower concentration in the APL cell line (NB4) than the current "arsenical gold standard", arsenic(III) oxide as Trisenox. ${ }^{9}$

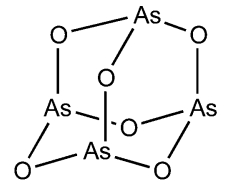

Arsenolite $\left(\mathrm{As}_{4} \mathrm{O}_{6}\right)$

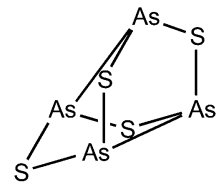

Realgar $\left(\alpha-\mathrm{As}_{4} \mathrm{~S}_{4}\right)$

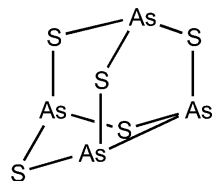

Uzonite $\left(\mathrm{As}_{4} \mathrm{~S}_{5}\right)$
We have now synthesized three sulfur derivatives of $( \pm)-1$ by reacting it with aqueous sodium sulfide in benzene. The heated mixture produces, by reductive desulfurization of the intermediate sulfur analog $( \pm)-2$, the chiral monosulfide $( \pm)-4$, which contains two As-As bonds and is structurally related to the mineral realgar $\left(\alpha-\mathrm{As}_{4} \mathrm{~S}_{4}\right)$, whereas the reaction at room temperature affords a separable mixture of diastereomeric chiral disulfides $( \pm)-\mathbf{3 a}$ and $( \pm)-\mathbf{3 b}$, each of which contains a single As-As bond and is structurally related to the mineral uzonite $\left(\mathrm{As}_{4} \mathrm{~S}_{5}\right)$. The monosulfide $( \pm)-4$ is considerably more potent and more selective than $( \pm)-1$ against the APL cells (NB4). The cell death mechanism induced by $( \pm)-1$ and $( \pm)-4$ involves promyelocytic leukemia (PML)-independent pathways, which has prompted further investigations into the therapeutic effects of these arsenical cages against certain ovarian and breast solid tumors.

\section{RESULTS AND DISCUSSION}

Synthesis of Arsenic-Sulfur Cages. In a preliminary investigation, a mixture of $( \pm)-1$ in benzene was treated with 3 equiv of sodium sulfide in water. The reaction mixture was stirred at room temperature and was monitored by ${ }^{1} \mathrm{H}$ NMR spectroscopy and mass spectrometry. Aliquots were removed from the benzene phase after $15 \mathrm{~min}, 2 \mathrm{~h}$, and $15 \mathrm{~h}$, and the residues (after drying and removal of solvent in vacuo) were dissolved in chloroform- $d$ and analyzed by ${ }^{1} \mathrm{H}$ NMR spectroscopy. The ${ }^{1} \mathrm{H}$ NMR spectrum of the 15 min sample contained resonances for unreacted $( \pm)-1$, the trisulfide $( \pm)-2$, and the diastereomers of the disulfide $( \pm)-3 \mathbf{a}$ and $( \pm)-3 \mathbf{b}$. The spectrum of the sample taken after $2 \mathrm{~h}$ showed mainly the disulfides and some of the trisulfide. The presence of the trisulfide in the initial sample was confirmed by mass spectrometric analysis of the evaporated residue of an aliquot taken from the reaction mixture. The ${ }^{1} \mathrm{H}$ NMR spectrum of the trisulfide ( \pm )-2 exhibits two doublets, one at $\delta 2.21$ and the other at $\delta 2.52$, both having the coupling constant ${ }^{2} J_{\mathrm{HH}}=12.3$ $\mathrm{Hz}$ for the magnetically equivalent pairs of outer methylene protons, and a singlet at $\delta 2.25$ for the inner methylene protons.
The HR-EI mass spectrum of the sample exhibited a molecular ion for ( \pm )-2 (found $m / z$ 437.6492, $\mathrm{C}_{3} \mathrm{H}_{6} \mathrm{As}_{4} \mathrm{~S}_{3}$ requires 437.6495). The third sample contained resonances for the disulfides only. The NMR spectra for the three samples are shown in Figure 1. In the presence of a large excess of aqueous sulfide, however, a further desulfurization of the disulfide $( \pm)-3 \mathbf{a} /( \pm)-3 \mathbf{b}$ occurs to give the monosulfide $( \pm)-4$. These data are consistent with the initial substitution of oxide by sulfide in the parent $( \pm)-\mathbf{1}$ to give the sulfur analog $( \pm)-2$, as an intermediate, which undergoes consecutive, reductive desulfurizations in the presence of additional sulfide to give the disulfides ( \pm )-3a and $( \pm)-3 \mathbf{b}$, and then the monosulfide $( \pm)-4$. Relatively little of the disulfide $( \pm)-3 b$ is produced in the reaction. Furthermore, when isolated disulfide $( \pm)-3 \mathbf{a}$ was treated with an excess of aqueous sodium sulfide, both the monosulfide $( \pm)-\mathbf{4}$ and the disulfide $( \pm)-3 b$ were produced, but no conversion of isolated $( \pm)-3 \mathbf{b}$ into $( \pm)-4$ was observed under similar conditions. When $( \pm)-1$ in benzene was heated with an excess of aqueous sulfide in water for $3 \mathrm{~h}$, however, only the monosulfide $( \pm)-4$ was observed.

Based on the exploratory investigation described above, the mono- and disulfide derivatives of $( \pm)-1$ were synthesized and structurally characterized. Thus, a solution of $( \pm)-1$ in benzene was treated with ca. 30 equiv of aqueous sodium sulfide and the mixture was heated under reflux for $3 \mathrm{~h}$. After a typical workup, the monosulfide $( \pm)-4$ was isolated in $52 \%$ yield as bright yellow needles, $\mathrm{mp}>165{ }^{\circ} \mathrm{C}$ (decomp) (Scheme 1). The monosulfide was also produced when the linear iodoarsine precursor to $( \pm)-\mathbf{1}$, the hexaiodoarsine $\mathbf{5}$, was heated with aqueous sulfide. The monosulfide $( \pm)-4$ is produced only when the benzene solution of $( \pm)-1$ is heated with a large excess of aqueous sulfide. Indeed, when 3 equiv of the sulfide was used in the reaction at room temperature, the disulfides $( \pm)-3 \mathbf{a}$ and $( \pm)-3 b$ were the only products observed. The diastereomers $( \pm)-3 \mathbf{a}$ and $( \pm)-\mathbf{3 b}$ were separated by column chromatography on silica by elution with $n$-hexane/dichloromethane $(8 / 2)$ and were isolated as air-stable crystalline solids, $\mathrm{mp}>216{ }^{\circ} \mathrm{C}$ (decomp) (pale yellow plates, $( \pm)-3 a$ ) and $\mathrm{mp}>162{ }^{\circ} \mathrm{C}$ (colorless octahedral crystals, $( \pm)-3 b$ ), both of which have been characterized by X-ray crystallography.

The $300 \mathrm{MHz}{ }^{1} \mathrm{H}$ NMR spectrum of the monosulfide $( \pm)-4$ in benzene- $d_{6}$ is consistent with the presence of three methylene groups in the molecule, two of which are magnetically equivalent because of $C_{2}$ symmetry. Thus, a single $\mathrm{AB}$ quartet at $\delta 1.17, \delta 1.27\left({ }^{2} \mathrm{~J}_{\mathrm{HH}}=12.3 \mathrm{~Hz}\right)$ was observed for the outer methylene protons and a singlet at $\delta 0.46$ for the inner methylene protons (Figure 2a). The spectrum of the disulfide ( \pm )-3a contains four sets of doublets at $\delta 0.54$ for $\mathrm{H}(1)\left({ }^{2} J_{\mathrm{HH}}=13.5 \mathrm{~Hz}\right), \delta 0.92$ for $\mathrm{H}(2)\left({ }^{2} J_{\mathrm{HH}}=13.5 \mathrm{~Hz}\right), \delta$ 1.54 for $\mathrm{H}(6)\left({ }^{2} \mathrm{~J}_{\mathrm{HH}}=12.3 \mathrm{~Hz}\right)$, and $\delta 3.12$ for $\mathrm{H}(4)\left({ }^{2} J_{\mathrm{HH}}=\right.$ $12.3 \mathrm{~Hz})$ and two sets of doublet of doublets at $\delta 2.68$ for $\mathrm{H}(3)$ and $\delta 2.97$ for $\mathrm{H}(5)$ with the coupling constants $\left({ }^{2} J_{\mathrm{HH}}=13.5\right.$ $\mathrm{Hz},{ }^{4} J_{\mathrm{HH}}=1.8 \mathrm{~Hz}$ ) (Figure $2 \mathrm{~b}$ ). These data are consistent with the presence of six chemically nonequivalent methylene protons in an asymmetric molecule $\left(C_{1}\right)$ with a single longrange, $\mathrm{W}$-coupling between the methylene protons $\mathrm{H} 3$ and $\mathrm{H} 5$. The spectrum of the diastereomer $( \pm)-3 b$ contains two sets of doublets for the magnetically equivalent pairs of outer methylene protons, one at $\delta 1.36$ and the other at $\delta 2.48$, with both resonances having the coupling constant ${ }^{2} J_{\mathrm{HH}}=12.3$ $\mathrm{Hz}$, and a singlet at $\delta 0.61$ for the inner methylene protons in the $\mathrm{C}_{2}$-symmetric structure (Figure $2 \mathrm{c}$ ). 
(a)

$3 a$<smiles>CCC(CC)CC</smiles><smiles>CCCCC</smiles>

$3 \mathbf{a}$

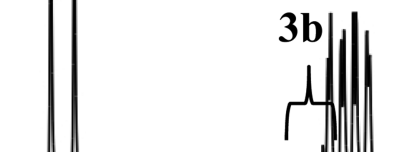

(1)

$\begin{array}{llllllllllllllllllllllllllll}4.0 & 3.9 & 3.8 & 3.7 & 3.6 & 3.5 & 3.4 & 3.3 & 32 & 3.1 & 3.0 & 2.9 & 2.8 & 2.7 & 2.6 & 2.5 & 2.4 & 2.3 & 2.2 & 2.1 & 2.0 & 1.9 & 1.8 & 1.7 & 1.6 & 1.5 & 1.4 & 1.3\end{array}$

(b)

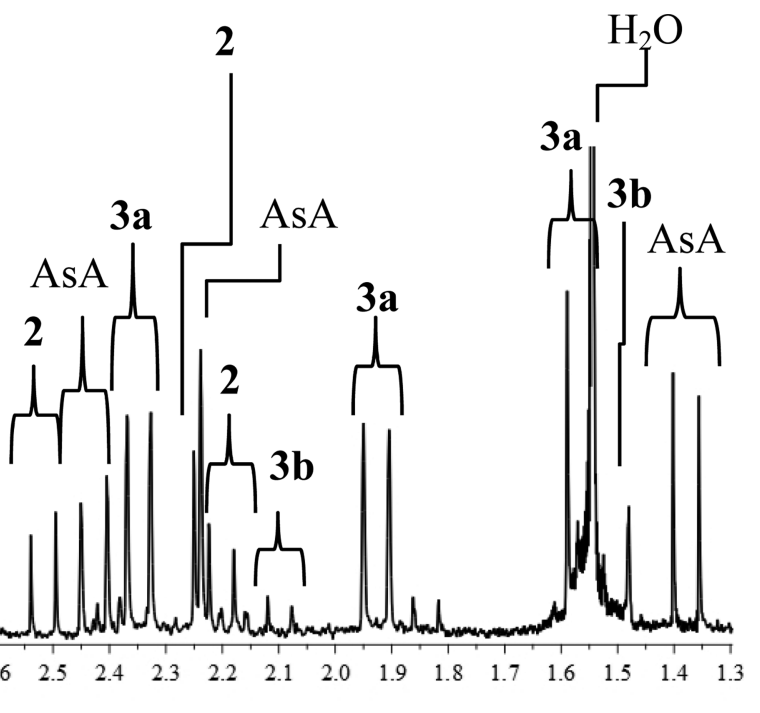

3<smiles>CCCCC</smiles>

$3 \mathbf{a}$

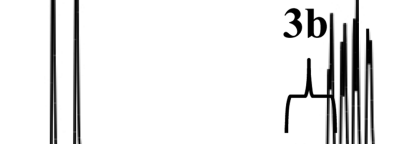

mond
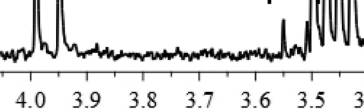

(c)

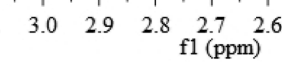

$\mathrm{H}_{2} \mathrm{O}$

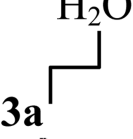<smiles>CCCCCC</smiles>

||<smiles>CCCCC</smiles>
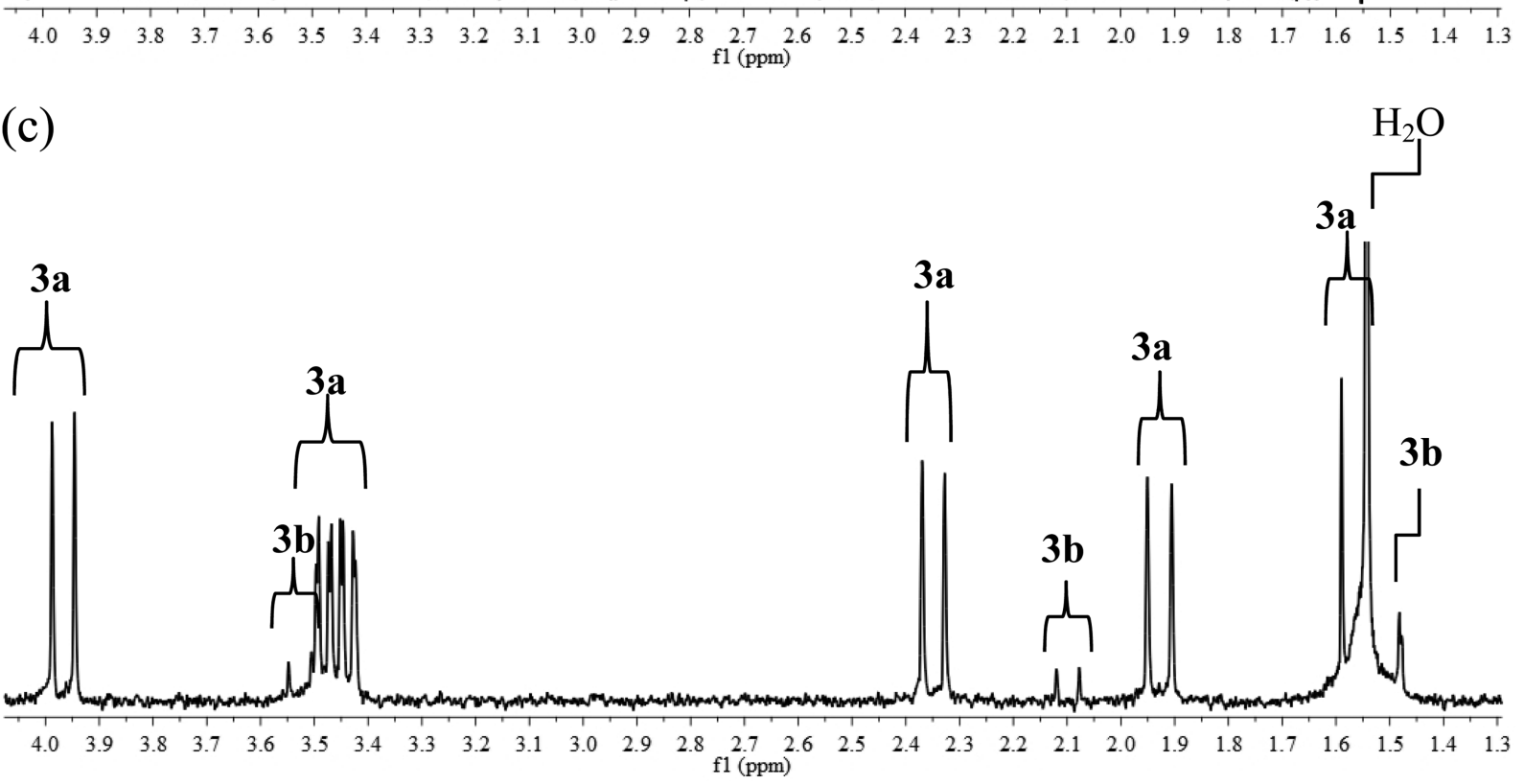

Figure 1. ${ }^{1} \mathrm{H}$ NMR $(300 \mathrm{MHz})$ spectra in chloroform- $d$ of samples of the reaction mixture containing $( \pm)-1$, in benzene and 3 equiv of aqueous sodium sulfide at room temperature were removed after $15 \mathrm{~min}(\mathrm{a}), 2 \mathrm{~h}(\mathrm{~b})$, and $15 \mathrm{~h} \mathrm{(c).}$

The UV/vis spectra of $( \pm)-\mathbf{4},( \pm)-\mathbf{3 a}$, and $( \pm)$-3b were recorded in dichloromethane. The photoelectronic spectra reveal that each of the arsenic-sulfur cages absorbs UV radiation in the absence of an obvious chromophore, as is the 
Scheme 1. Synthesis of Sulfur Derivatives of Arsenicin A

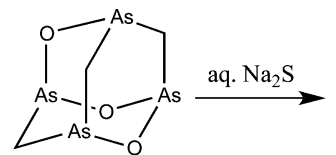

$( \pm)-1$

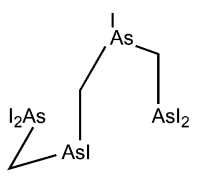

Hexaiodoarsine
Arsenicin A (AsA)

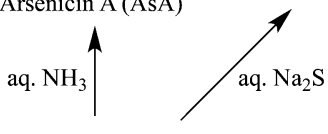

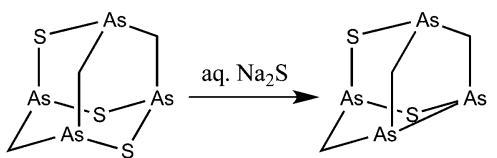

$( \pm)-2$

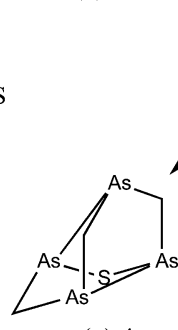

$( \pm)-4$
$( \pm)-3 a$

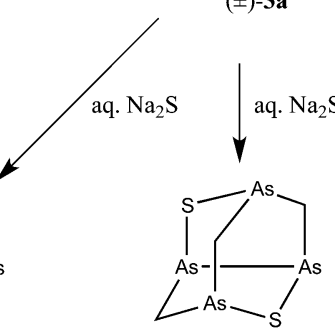

$( \pm)-3 \mathbf{b}$ case for the parent compound $( \pm)-1{ }^{9}$ The spectrum of the monosulfide $( \pm)-4$ contains peaks at $\lambda_{\max } / \mathrm{nm}\left[\mathrm{CH}_{2} \mathrm{Cl}_{2}(\varepsilon /\right.$ $\left.\left.\left(\mathrm{dm}^{3} \mathrm{~mol}^{-1} \mathrm{~cm}^{-1}\right)\right)\right]: 322$ (942), 278 (6017), 249 (17 527), and 236 (16 650). The spectra of the disulfides $( \pm)-3 a$ and ( \pm )-3b contain peaks at 309 (2229), 280 (3942), 256 (6113), and 232 (10 405), and 315 (1680), 280 (2866), 248 (5228), and 231 (8110), respectively. Theoretical investigations using time-dependent density functional theory (TD-DFT) revealed that the absorptions in the three compounds are facilitated by through-space and through-bond interactions between p-type nonbonding orbitals on arsenic atoms, denoted by $A s(p)$ and $\mathrm{S}(\mathrm{p})$, and the $\sigma$-bonding framework (As-C and As-S) of the molecules, which destabilize occupied and stabilize unoccupied molecular orbitals (see Appendix S1 of the Supporting Information for detailed results and analysis).

Resolutions. The resolutions of ( \pm )-4, ( \pm )-3a, and ( \pm )-3b were investigated by HPLC with use of a Chiralpak IA column $(5 \mu \mathrm{m}, 250 \mathrm{~mm} \times 4.6 \mathrm{~mm}$ ID). After an initial screening, the three resolutions were achieved by elution with premixed dichloromethane $/ n$-hexane $(2 / 8)$ and a flow rate of $1 \mathrm{~mL} / \mathrm{min}$ with the separation being monitored at $254 \mathrm{~nm}$. The resolution of the three arsenic-sulfides was achieved under these conditions with efficiencies of $>99 \%$. The individual enantiomers of the arsenic-sulfur cages did not racemize in dichloromethane/ $n$-hexane $(2 / 8)$ over 2 days at room temperature. Chromatograms showing the resolutions of $( \pm)-4,( \pm)-3 a$, and $( \pm)-3 b$ are shown in Figure 3.

Crystallography. The crystal structures of $( \pm)-4,( \pm)-3 a$, and $( \pm)-3 b$ have been determined by X-ray diffraction. For the three compounds, refinement by conventional methods yielded structures with unusual displacement parameters, and bond lengths and angles that seemed chemically implausible. This suggested that there was a packing disorder of the molecules within the unit cell and/or twinning. The specialist X-ray structure refinement program RAELS06 was used to overcome these complications using the minimum number of parameters. $^{12}$

The monosulfide ( \pm )-4 crystallizes from benzene as a racemic compound. The structure is disordered and was refined in the monoclinic space group $C 2 / c$ using a common set of local coordinates to describe the overlapping structures. A molecule having the sulfur atom on the 2-fold axis has the dominant probability, $0.874(4)$, and has a crystallographically imposed symmetry of 2 . The remaining two components are related by the 2 -fold axis and were the only alternative orientations found. The site symmetry restricts the TLX model to 9 independent variables. The molecule has pseudo $D_{2 d}$ symmetry, and the additional configurations are related by the mirror planes of $D_{2 d}$. This superimposes the new $S$ position $S 1^{\prime}$ on either $\mathrm{C} 1$ or the rotation related $\mathrm{C} 3$. The structure of the enantiomer $\left(1 S_{\mathrm{As}}, 3 S_{\mathrm{As}}, 5 R_{\mathrm{As}}, 7 R_{\mathrm{As}}\right)-4$ is shown in Figure 4 . The structure contains two As-As bonds and resembles that of the mineral realgar $\left(\alpha-\mathrm{As}_{4} \mathrm{~S}_{4}\right)$, in which three of the sulfur atoms have been replaced by methylene groups. The molecule has approximately $C_{2}$ symmetry with the 2 -fold axis passing through $\mathrm{S} 1$ and $\mathrm{C} 2$. The organometallic cage contains two pairs of stereogenic centers; the pair of As atoms bonded to As, $S$, and C (As1 and A3) has the same but opposite relative configuration as those bonded to As and two $\mathrm{C}$ atoms (As2 and As4). The mean bond lengths ( $\AA$ ) and angles (deg) in monosulfide $( \pm)-4$ are the following: As - As $=2.498(1)$, As $-\mathrm{S}$ $=2.237(1), \mathrm{As}-\mathrm{C}=1.970(2), \mathrm{S}-\mathrm{As}-\mathrm{C}=92.8(1), \mathrm{S}-\mathrm{As}-\mathrm{As}=$ 98.2(1), C-As-As = 95.1(10), C-As-C = 90.5(1), As-C-As $=112.8(6)$. The As-As and As $-S$ distances in $( \pm)-4$ are similar to those in realgar $\left(\alpha-\mathrm{As}_{4} \mathrm{~S}_{4}\right)$ of $D_{2 d}$ symmetry, where each As atom in the $D_{2 d}$ structure binds one As and two $S$ atoms. ${ }^{13}$ Realgar crystallizes in the space group $P 2_{1} / n$ with average As-As and As-S distances of 2.569(3) $\AA$ and 2.237(6) Å, respectively. ${ }^{14}$

The disulfide $( \pm)$-3a crystallizes from benzene as a racemic compound. The crystallographic asymmetric unit contains one molecule, which is disordered in its orientation. The structure was refined in the space group $P 2_{1} / n$ using a common set of local coordinates to describe the overlapping molecules. Weak restraints were used to match As-C distances. These restraints were easily satisfied, implying the refinement was incapable of detecting significant differences in these distances. The structure of the $\left(1 S_{\mathrm{As}}, 3 R_{\mathrm{As}}, 5 S_{\mathrm{As}}, 7 S_{\mathrm{As}}\right)$-3a enantiomer of the compound is shown in Figure 5. The mean bond lengths $(\AA)$ and angles (deg) in ( \pm )-3a are the following: As-As = 2.456(1), As-S = 2.244(7), As-C = 2.001(3), $\mathrm{S}-\mathrm{As}-\mathrm{C}=$ 101.0(38), S-As-As = 98.6(1), As-S-As = 108.9(39), CAs-As = 99.0(9), C-As-C = 99.1(4), As-C-As = 116.0(5), $S-A s-S=105.1(1)$.

The disulfide diastereomer $( \pm)-3 \mathbf{b}$ crystallizes from benzene as colorless octahedra in the space group $\mathrm{P}_{3}$. The crystal selected showed significant twinning, although there was no disorder. The crystallographic unit consists of one molecule, with the twinned components having opposite handedness. The structure of the $\left(1 R_{\mathrm{As}}, 3 R_{\mathrm{As}}, 5 R_{\mathrm{As}}, 7 R_{\mathrm{As}}\right)$ enantiomer of the compound is shown in Figure 6. The mean bond lengths $(\AA)$ and angles (deg) in ( \pm )-3b are the following: As-As = 2.247(1), As-S = 2.244(2), As-C = 1.984(7), S-As-C = 99.2(24), S-As-As = 98.0(1), As-S-As = 104.4(4), C-AsAs $=100.0(4), \mathrm{C}-\mathrm{As}-\mathrm{C}=102.5(2)$, As-C $-\mathrm{As}=121.4(49)$.

The structures of the disulfides $( \pm)-3 \mathbf{a}$ and $( \pm)-3 \mathbf{b}$ are related to that of the mineral uzonite $\left(\mathrm{As}_{4} \mathrm{~S}_{5}\right)$, in which three of the sulfur atoms have been replaced by methylene groups. The diastereomer $( \pm)-3 \mathbf{b}$ has approximately $C_{2}$ symmetry with the 2 -fold rotation axis passing through $\mathrm{C} 1$ and the midpoint of the As1-As 2 bond. The four stereogenic, arsenic centers in $( \pm)-3 b$ have the same relative configuration, and three of the four in the diastereomer $( \pm)-3 \mathbf{a}$ have the same configuration. The AsAs and As-S distances in ( \pm )-3a and $( \pm)-3 \mathbf{b}$ are similar to those reported for the mineral uzonite, viz. $2.527 \AA$ (As-As) and 2.237-2.261 $\AA$ (As-S). ${ }^{15}$

Biological Activity. We have shown previously that the parent arsenical $( \pm)-\mathbf{1}$ (AsA) is more potent than arsenic(III) 
(a)
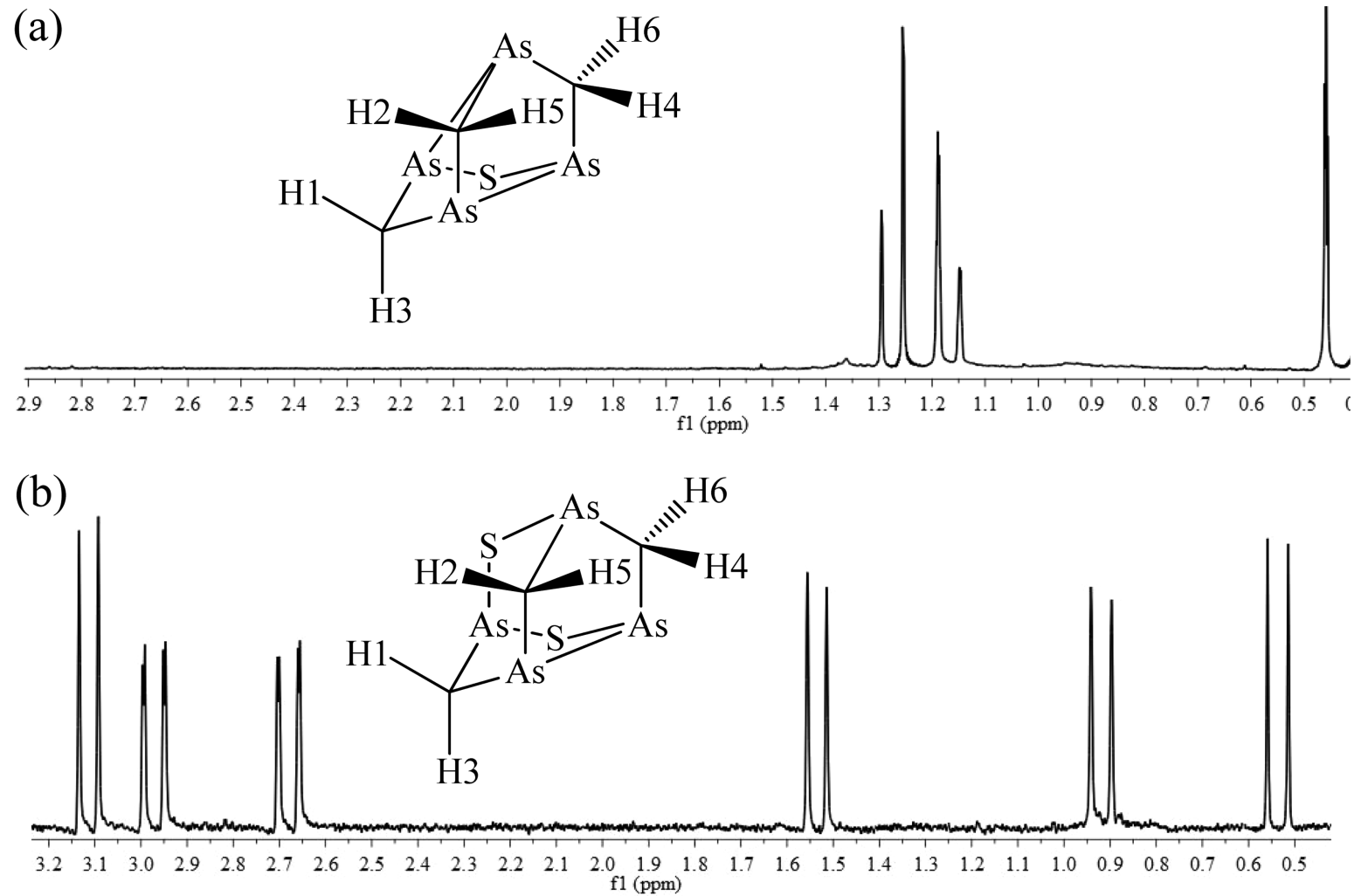

(c)

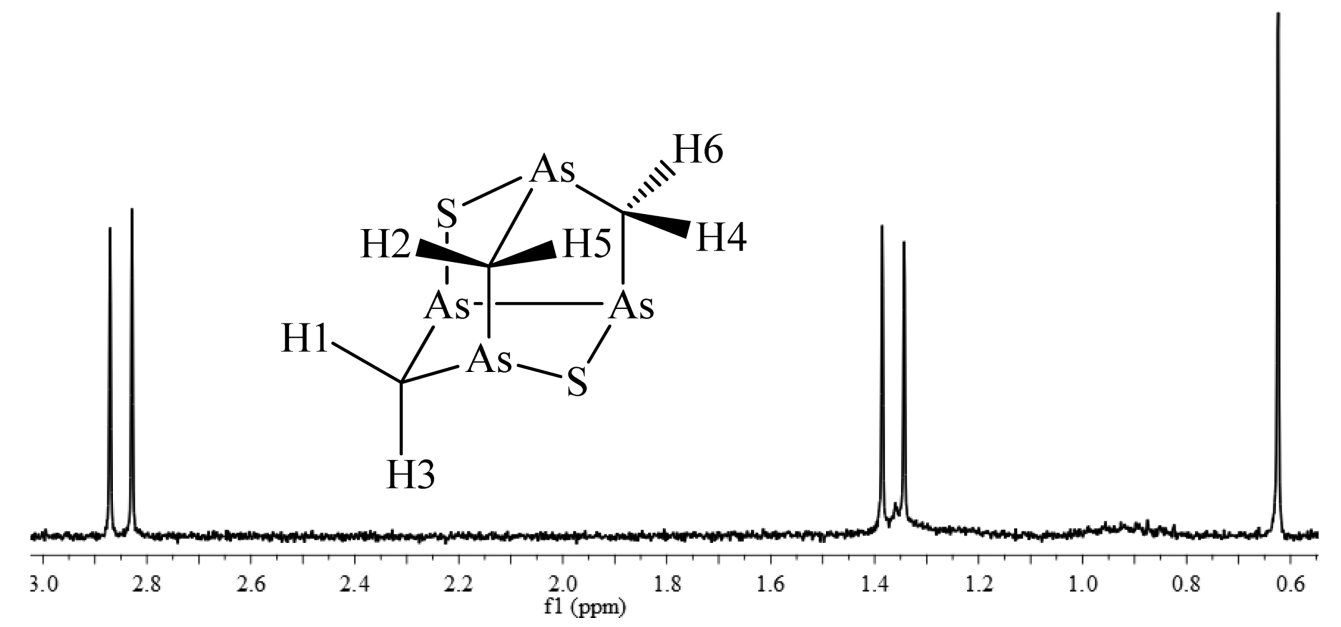

Figure 2. ${ }^{1} \mathrm{H}$ NMR $(300 \mathrm{MHz})$ spectra in benzene- $d_{6}$ of monosulfide $( \pm)-\mathbf{4}(\mathrm{a})$, disulfide $( \pm)-\mathbf{3 a}(\mathrm{b})$, and disulfide $( \pm)-3 \mathbf{b}(\mathrm{c})$.

trioxide for the induction of proliferation arrest and cell death of acute PML cells (NB4) bearing the chromosome $t(15 ; 17)$ translocation generating the PML-RARA fusion gene. ${ }^{9}$ We have now demonstrated that the monosulfide $( \pm)-4$ is an ca. 3 -fold better inhibitor than the parent $( \pm)-1$ for these cells. The $72-\mathrm{h}$ $\mathrm{IC}_{50}$ values (concentration of compound that inhibits proliferation by $50 \%$ ) for ( \pm )-1 and ( \pm )-4 are $55 \pm 13 \mathrm{nM}$ and $22 \pm 1 \mathrm{nM}$, respectively (Table 1 ). The effect of the two compounds was also tested on differentiated cells. The NB4 cells were treated with all-trans retinoic acid. Interestingly, NB4 differentiation was responsible for a decrease in the activity of ( \pm )- 1 but had no effect on the activity of $( \pm)-4$ or, as described by Mandegary and Mehrabani, ${ }^{16}$ on arsenic(III) oxide (not shown). In non-APL and in APL cells, arsenic(III) oxide binds PML or the PML part of PML/RARA fusion proteins and induces its oxidation. ${ }^{17}$ This yields to PML multimerization from the nucleoplasm, NB assembly, PML hypersumoylation, and degradation. On the contrary, in mouse embryonic fibroblast cells stably expressing PML (MEF-PML), neither ( \pm )-1 nor ( \pm )-4 induced PML hypersumoylation (Figure 7a), degradation (Figure $7 \mathrm{~b}$ ), or the recruitment of the nucleoplasmic form of PML into nuclear bodies (NB) (Figure 7c). Thus, neither $( \pm)-\mathbf{1}$ nor $( \pm)-\mathbf{4}$ target PML, which suggests mechanistic pathways different from those targeting the leukemia-initiating oncoprotein are involved in the clearance of the cancerous cells.

The monosulfide $( \pm)-4$ was consistently more potent than the naturally occurring parent $( \pm)-1$ for the induction of proliferation arrest of solid tumors (ovarian and breast carcinomas) (Table 2). For SKOV-3, 2008, and MDA-MB231 cells, the $\mathrm{IC}_{50}$ values for proliferation inhibition by ( \pm )-4 indicate 3-, 2-, and 5-fold greater potency than ( \pm )-1, 

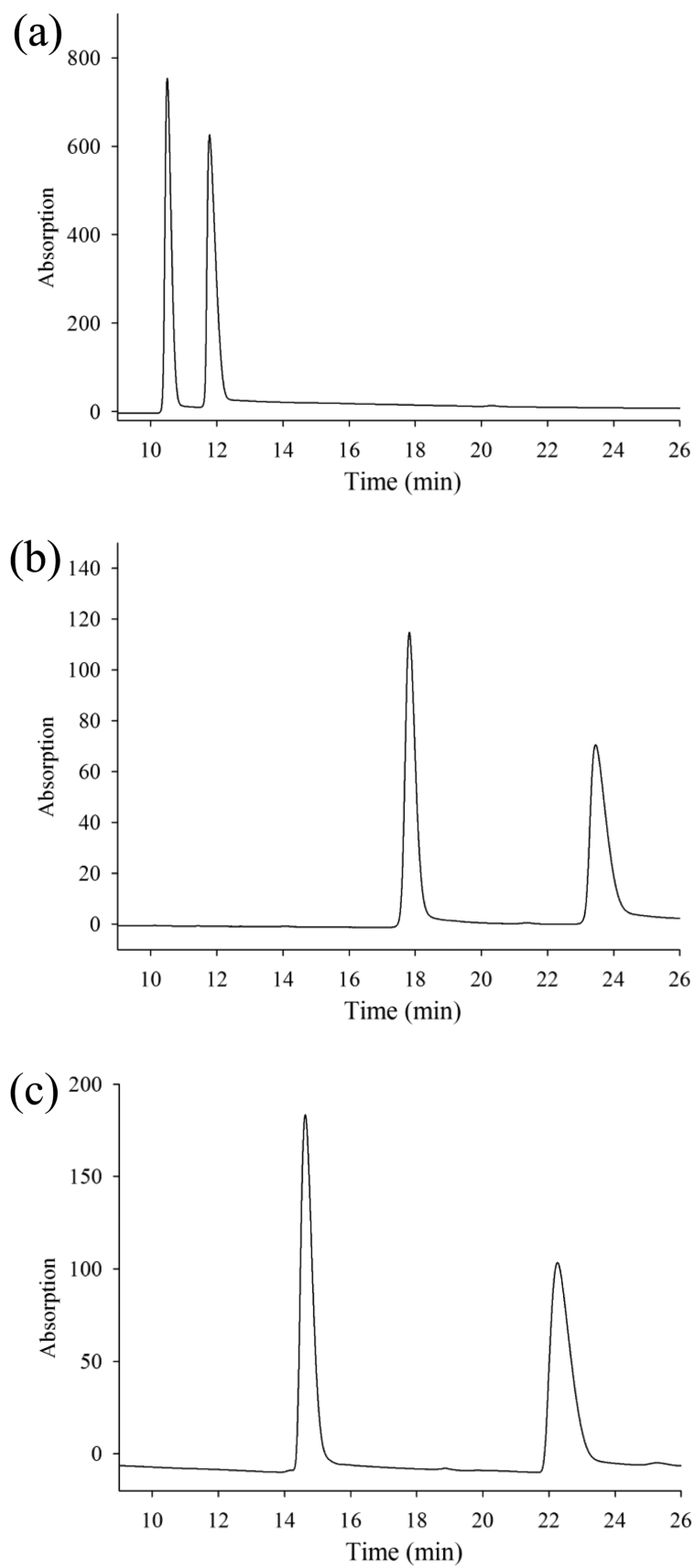

Figure 3. Resolutions of $( \pm)-4(a),( \pm)-3 a(b)$, and $( \pm)-3 b(c)$ on a Chiralpak IA column by elution with dichloromethane/ $n$-hexane (2/ 8).

respectively. Moreover, because $( \pm)-4$ is better tolerated than $( \pm)-1$ by noncancerous cells (HOSE 17.1 and MCF 10A), the improved antiproliferative activities for $( \pm)-4$ translate into better selectivity for the cancer cells [selectivity values are 4-30 for ( \pm )-4 and 1-7 for ( \pm )-1 (Table 2)]. The MDA-MB-231 cells were taken from a triple negative breast cancer that does not express estrogen receptor, progesterone receptor, or Her2, which renders them difficult to treat because most chemotherapies target at least one of these receptors. The antiproliferative activity described here for the monosulfide ( \pm )-4 (in the low nanomolar range) accompanied by the good selectivity is a particularly promising development for the treatment of these cancers. ${ }^{18}$

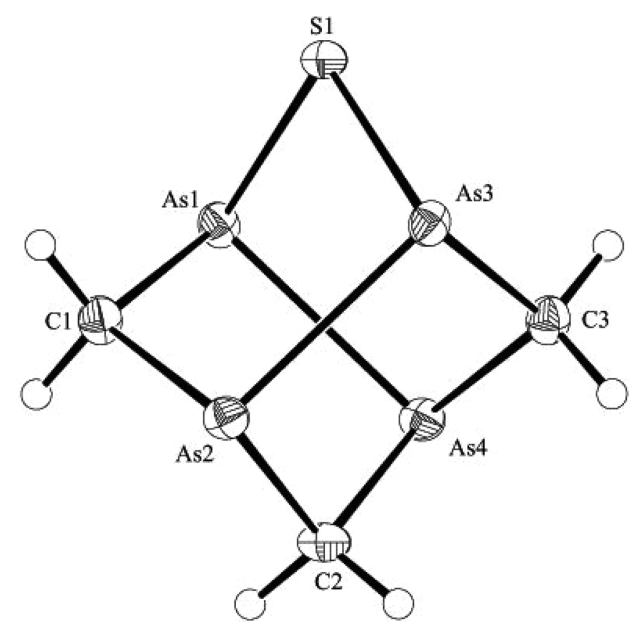

Figure 4. Structure of the $\left(1 S_{\mathrm{As}}, 3 S_{\mathrm{As}}, 5 R_{\mathrm{As} s}, 7 R_{\mathrm{As}}\right)-4$ showing $30 \%$ probability ellipsoids. Selected distances $(\AA)$ and angles (deg): As1As4 = 2.498(1), As $1-\mathrm{S} 1=2.237(1)$, As $1-\mathrm{C} 1=1.970(2), \mathrm{S} 1-\mathrm{As} 1-$ $\mathrm{C} 1=92.8(1), \mathrm{S} 1-\mathrm{As} 1-\mathrm{As} 4=98.2(1), \mathrm{As} 1-\mathrm{S} 1-\mathrm{As} 3=98.4(1), \mathrm{C} 1-$ As1-As4 = 94.6(1), C1-As2-As3 = 96.4(1), C2-As2-As3 = 94.2(1), C2-As4-As1 = 94.2(1), C3-As3-As2 = 94.6(1), C3As4-As1 = 96.4(1), C1-As2-C2 = 90.5(1), As1-C1-As2 = 113.1(1), As2-C2-As4 = 112.3(1), As3-C3-As4 = 113.1(1).

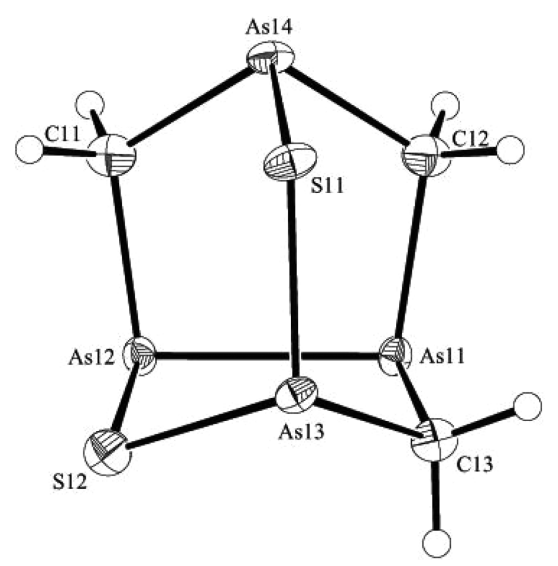

Figure 5. Structure of the $\left(1 S_{\mathrm{As}}, 3 R_{\mathrm{As}}, 5 S_{\mathrm{As}}, 7 S_{\mathrm{As}}\right)$-3a showing $30 \%$ probability ellipsoids. Selected bond distances $(\AA)$ and angles (deg): As11-As12 = 2.456(1), As12-S12 = 2.236(2), As13-S11 = 2.251(1), As13-S12 = 2.237(2), As14-S11 = 2.250(1), As11-C13 = 2.001(3), $\mathrm{S} 11-\mathrm{As} 13-\mathrm{C} 13=106.3(3), \mathrm{S} 11-\mathrm{As} 14-\mathrm{C} 11=104.3(4), \mathrm{S} 11-$ $\mathrm{As} 14-\mathrm{C} 12=98.0(4), \mathrm{S} 12-\mathrm{As} 12-\mathrm{C} 11=100.3(4), \mathrm{S} 12-\mathrm{As} 13-\mathrm{C} 13=$ 96.2(3), S12-As12-As11 = 98.6(1), As12-S12-As13 = 105.0(1), As13-S11-As14 = 112.8(1), C11-As12-As11 = 98.2(2), C12As11-As12 = 98.5(2), C13-As11-As12 = 100.3(2), C11-As14$\mathrm{C} 12=98.7(4), \mathrm{C} 12-\mathrm{As} 11-\mathrm{C} 13=99.5(4)$, As11-C12-As14 = 116.2(2), As11-C13-As13 = 115.3(2), As12-C11-As14 = 116.5(3), S11-As3-S12 = 105.1(1).

We have also found that the parent cage $( \pm)-1$ and the monosulfide derivative $( \pm)-4$ induce apoptosis in a drug resistant ovarian cancer cell line (SKOV-3). Annexin-V and propidium iodide staining revealed that cells treated for $24 \mathrm{~h}$ undergo apoptosis in response to $( \pm)-1$ and $( \pm)-4$ exposure. Cells entering apoptosis (early apoptotic cells) express phosphatidylserine at their surface and are stained by Annexin-V (Figure 8, AnnV+/PI-). Late apoptotic cells with impaired plasma membrane integrity are stained by both propidium iodide (DNA binding) and Annexin-V (Figure 8, AnnV+/PI+). A dose-dependent induction of apoptosis (early 


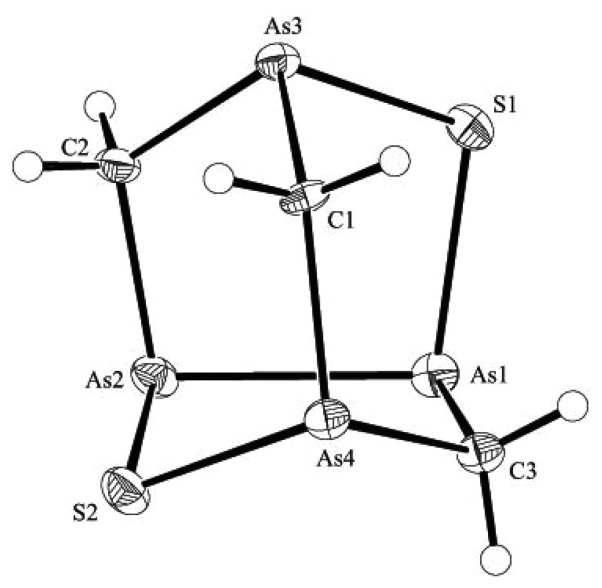

Figure 6. Structure of $\left(1 R_{\mathrm{As}}, 3 R_{\mathrm{As}}, 5 R_{\mathrm{As}}, 7 R_{\mathrm{As}}\right)-3 \mathbf{b}$ showing $30 \%$ probability ellipsoids. Selected bond distances $(\AA)$ and angles (deg): As-As $=2.479(1)$, As1-S1 = 2.245(1), As2-S2 = 2.243(1), As3-S1 $=2.241(1)$, As4 $-\mathrm{S} 2=2.245(1), \mathrm{As} 1-\mathrm{C} 3=1.990(2)$, As2 $-\mathrm{C} 2=$ $1.990(2)$, As3 $-\mathrm{C} 1=1.976(2)$, As3 $-\mathrm{C} 2=1.989(2)$, As4 $-\mathrm{C} 1=$ 1.975(2), As4-C3 = 1.989(2), C3-As1-S1 = 99.8(1), C2-As2-S2 = 98.3(2), C1-As3-S1 = 102.6(1), C2-As3-S1 = 96.1(1), C3-As4$\mathrm{S} 2=96.8(1), \mathrm{C} 1-\mathrm{As} 4-\mathrm{S} 2=101.7(1), \mathrm{S} 1-\mathrm{As} 1-\mathrm{As} 2=98.0(1), \mathrm{As} 1-$ S1-As3 = 104.0(1), As2-S2-As4 = 104.7(1), C2-As2-As1 = 99.6(1), C3-As1-As2 = 100.4(1), C1-As3-C2 = 102.5(2), C1As4-C3 $=102.4(2)$, As3-C1-As4 = 128.3(2), As2-C2-As3 = 118.2(2), As1-C3-As4 = 117.6(2).

Table 1. Effect of $( \pm)-1\left(\right.$ AsA) and $( \pm)-4$ on APL Cells ${ }^{a}$

\begin{tabular}{lccc} 
& \multicolumn{3}{c}{ NB4 } \\
\cline { 2 - 4 } & \multicolumn{3}{c}{ APL cells } \\
\cline { 2 - 4 } & $\mathrm{As}_{2} \mathrm{O}_{3}$ & AsA & $( \pm)-4$ \\
$\mathrm{IC}_{50}(\mathrm{nM})$ & 1070 & 55 & 22 \\
$\mathrm{SD}$ & 190 & 13 & 1 \\
ratio & & 19 & 49 \\
selectivity & 30 & 11 & 44
\end{tabular}

${ }^{a} \mathrm{IC}_{50}$ values for proliferation inhibition are the means from at least two experiments carried out in duplicates. SD: standard deviation. Ratio = $\mathrm{IC}_{50}\left(\mathrm{As}_{2} \mathrm{O}_{3}\right) / \mathrm{IC}_{50}$ for $( \pm)-1$ (AsA) or monosulfide $( \pm)$-4. Selectivity $=\mathrm{IC}_{50}$ (arsenical drug on normal MRC 5 cells) $/ \mathrm{IC}_{50}$ (arsenical drug on cancer cell lines).

+ late apoptotic cells) was observed for both compounds. The parental compound $( \pm)-1$ appears to be more pro-apoptotic than its monosulfide derivative $( \pm)-4$. The relative absence of cells stained only by propidium iodide (Figure $8, \mathrm{AnnV}-/ \mathrm{PI}-$ ) in response to the drug treatments indicated that the cells were not undergoing necrosis.

Arsenic-based compounds and arsenic trioxide in particular are responsible for defects in cell proliferation due, at least in part, to the induction of oxidative stress through the production and accumulation of reactive oxygen species. ${ }^{18}$ Since it has been demonstrated by us and others that the glutathione (GSH) homeostasis regulates the cellular redox status and protects cells from arsenic-based compounds oxidant-induced injuries, ${ }^{19-22}$ the parent cage $( \pm)-1$ and the monosulfide derivative $( \pm)-4$ were tested on cells in the presence of free membranepermeable glutathione (glutathione ethyl ester) or L-buthionine sulfoximine (BSO, an inhibitor of GSH synthesis). As anticipated, GSH and BSO were able to block and enhance the antiproliferative activity of both compounds (Figure 9), respectively. These findings indicate clearly that an oxidative stress generated by $( \pm)-\mathbf{1}$ and its monosulfide derivative $( \pm)-4$ takes an important place in the mechanism by which these compounds induce cancer cell proliferation arrest.

Organic arsenic(III) often shows thiol reactivity with dithiol groupings from closely spaced cysteine residues of proteins. This dithiol reactivity can be measured by an arsenic(III) titration with 2,3-dimercapto-1-propanol (DMP) and 5,5'dithiobis(2-nitrobenzoic acid) (DTNB). ${ }^{23}$ We have compared the dithiol binding capacities of $( \pm)-1$ and $( \pm)-4$. The parent cage $( \pm)-1$ binds two dithiol groups per molecule $(8.6 \mu \mathrm{mol}$ $( \pm)-1$ binds $18.4 \mu \mathrm{mol}$ of DMP); ( \pm )-4 shows low dithiol affinity (0.2 dithiol bound per molecule) (Figure 10). The ability to bind closely spaced pairs of protein dithiol groups (from cysteine residues) is a defining characteristic of arsenicbased anticancer agents such as arsenic(III) oxide, 4-(N-((S)glutathionylacetyl)amino)phenylarsonous acid (GSAO), and 4$(N((S)$-penicillaminylacetyl)amino) phenylarsonous acid (PENAO) and is essential to their mechanism of action. ${ }^{20,24,25}$

We have confirmed here our earlier observation that each molecule of $( \pm)-1$ binds two pairs of cysteine-dithiol groups, which is consistent with the cage in aqueous solution having the open, terminal bis(arsonous acid) structure $\mathrm{CH}_{2}[\mathrm{As}(\mathrm{OH})$ $\left.\mathrm{CH}_{2} \mathrm{As}(\mathrm{OH})_{2}\right]_{2} .{ }^{9}$ The observation that the monosulfide $( \pm)-4$ does not bind these dithiol groupings indicates that its mechanism of action differs from those of other trivalent organic arsenicals investigated. ${ }^{11}$

\section{CONCLUSION}

Three sulfur derivatives of the naturally occurring tetraarsenical Arsenicin A, $( \pm)-1$, have been synthesized by the reaction of a benzene solution of the organometallic arsenic-oxygen cage with aqueous sodium sulfide: the monosulfide cage $( \pm)-4$, which contains two As-As bonds and is structurally related to the mineral realgar $\left(\alpha-\mathrm{As}_{4} \mathrm{~S}_{4}\right)$, and the disulfide cages $( \pm)-3 \mathrm{a}$ and $( \pm)-3 \mathbf{b}$, each of which contains one As-As bond and is structurally related to the mineral uzonite $\left(\mathrm{As}_{4} \mathrm{~S}_{5}\right)$. The resolutions of $( \pm)-4,( \pm)-3 \mathbf{a}$, and $( \pm)-3 \mathbf{b}$ were achieved by chiral HPLC on a Chiralpak IA column; the individual enantiomers of each sulfide derivative showed no racemization in dichloromethane/ $n$-hexane $(2 / 8)$ over 2 days at room temperature. Biological investigations indicate that the monosulfide $( \pm)-4$ is more potent against APL cells than the parent ( \pm )-1 and arsenic(III) oxide. The mechanism of action of the cages $( \pm)-1$ and $( \pm)-4$ also appears to differ from that of arsenic(III) oxide. PML degradation does not appear to proceed through SUMO-dependent polyubiquitination for $( \pm)-1$ and $( \pm)-4$. When tested against solid cancer derived cell lines, both $( \pm)-1$ and $( \pm)-4$ were shown to induce apoptosis; however, $( \pm)-4$ demonstrated stronger oxidative stress-induced antiproliferative activity and better selectivity. Furthermore, because there is no significant dithiol reactivity observed for the monosulfide derivative $( \pm)-4$, a new mechanism for cancer cell proliferation inhibition and cell death induction is in operation for this compound. The antiproliferative activity and selectivity of $( \pm)-4$ warrant further investigation.

\section{EXPERIMENTAL SECTION}

General Comments. Manipulations involving air-sensitive compounds were carried out under a dry and oxygen-free nitrogen atmosphere with use of standard Schlenk and vacuum-line techniques. Solvents were dried over appropriate drying agents and distilled before use. ${ }^{26}$ Routine NMR spectra were recorded at $25{ }^{\circ} \mathrm{C}$ on a Varian 
(a)

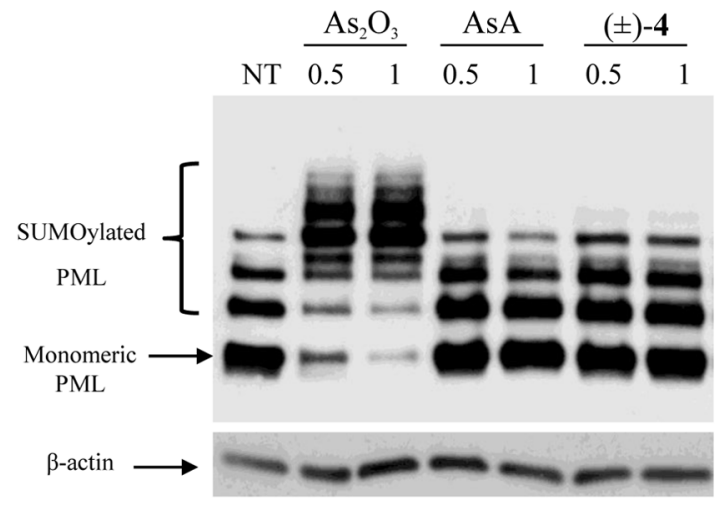

(b)

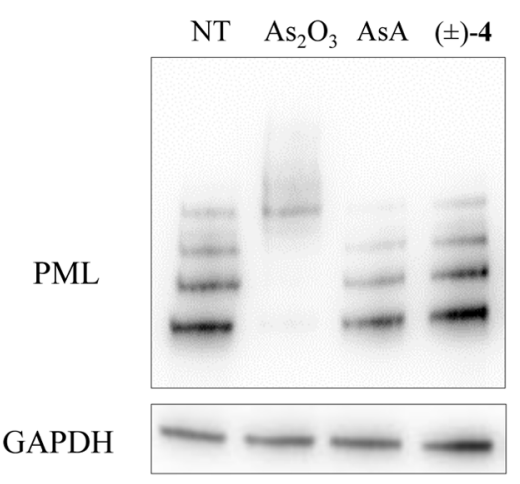

(c)

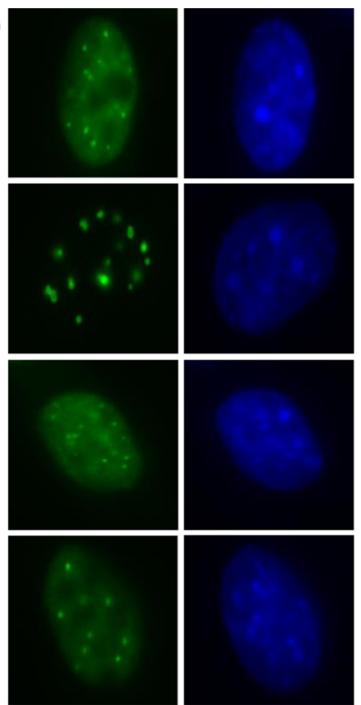

NT

$\mathrm{As}_{2} \mathrm{O}_{3}$

AsA

$( \pm)-4$

Figure 7. Effect of arsenic(III) oxide $\left(\mathrm{As}_{2} \mathrm{O}_{3}\right),( \pm)-1$ (AsA), and monosulfide ( \pm )-4 on PML: (a) PML SUMOylation (MEF-PML cells were treated or not (NT) for $1 \mathrm{~h}$ with 1 or $0.5 \mu \mathrm{M}$ of the arsenicals; $\beta$-actin detection is shown as loading control; the Western blot is representative of three independent experiments); (b) PML degradation (MEF-PML cells were treated for $9 \mathrm{~h}$ with $1 \mu \mathrm{M}, 10 \mathrm{nM}$ and $5 \mathrm{nM} \mathrm{As} \mathrm{O}_{3}$, ( \pm )-1, and $( \pm$ )-4, respectively; GAPDH detection is shown as loading control; the Western blot is representative of three independent experiments); (c) PML recruitment in nuclear bodies (MEF-PML cells were treated for $1 \mathrm{~h}$ with $2 \mu \mathrm{M}$ of $\mathrm{As}_{2} \mathrm{O}_{3}$ and $20 \mathrm{nM}$ of $( \pm)-1$ and $10 \mathrm{nM}$ of $\left.( \pm)-4\right)$. Fluorescent images are representative of two experiments.

Table 2. Effect of $( \pm)-1$ (AsA) and Monosulfide $( \pm)-4$ on Ovarian and Breast Cancer Cells ${ }^{a}$

\begin{tabular}{|c|c|c|c|c|c|c|}
\hline & \multirow{2}{*}{\multicolumn{2}{|c|}{$\frac{\text { SKOV-3 }}{\text { ovary }}$}} & \multirow{2}{*}{\multicolumn{2}{|c|}{$\begin{array}{l}2008 \\
\text { ovary }\end{array}$}} & \multirow{2}{*}{\multicolumn{2}{|c|}{$\frac{\text { MDA-MB-231 }}{\text { breast }}$}} \\
\hline & & & & & & \\
\hline & AsA & $( \pm)-4$ & AsA & $( \pm)-4$ & AsA & $( \pm)-4$ \\
\hline $\mathrm{IC}_{50}(\mathrm{nM})$ & 603 & 185 & 88 & 47 & 217 & 45 \\
\hline SD & 165 & 49 & 9 & 4 & 41 & 19 \\
\hline ratio & & 3 & & 2 & & 5 \\
\hline selectivity & 1 & 4 & 5 & 14 & 7 & 30 \\
\hline
\end{tabular}

${ }^{a} \mathrm{IC}_{50}$ values for proliferation inhibition are the means from at least two experiments carried out in duplicates. SD: standard deviation. Ratio $=$ $\mathrm{IC}_{50}( \pm)-1 / \mathrm{IC}_{50}( \pm)-4$. Selectivity values were calculated as follows: Selectivity $=\mathrm{IC}_{50}$ (arsenical drug on noncancerous cells) $/ \mathrm{IC}_{50}$ (arsenical drug on cancer cell lines). Drug selectivity toward ovarian and breast cancer cells was determined using HOSE 17.1 (normal ovarian surface epithelium) and MCF 10A (noncancerous breast epithelium), respectively.
Gemini 300BB spectrometer $\left({ }^{1} \mathrm{H}\right.$ NMR at $300.066 \mathrm{MHz}$ and ${ }^{13} \mathrm{C}\left\{{ }^{1} \mathrm{H}\right\}$ at $75.428 \mathrm{MHz}$ ). EI mass spectra were recorded on a Micromass (Waters) VG Autospec magnetic sector mass spectrometer at $800 \mathrm{RP}$, run against PFK calibrant and formulated by the MassLynx 4.0 elemental program. ESI mass spectra were recorded on a Waters LCT Premier XE instrument at 10,000 RP. The UV/vis spectra of ( \pm )-3a, $( \pm)-3 b$, and $( \pm)-4$ were recorded in a $1 \mathrm{~cm}$ cell with use of a SHIMADZU UV-2450 UV-visible spectrophotometer. Elemental microanalyses were performed by the microanalytical service of the Australian National University. The compounds ( \pm )-1 and the hexaiodoarsine 5 were synthesized as previously described. ${ }^{9}$

$\left(R *_{A s} R *_{A s} S{ }_{A s} S *_{A S}\right)$-2-Thia-1,3,5,7-tetraarsatricyclo[3.3.0.0 ${ }^{3,7}$ ]octane, $( \pm)-4$. A solution of $\mathrm{Na}_{2} \mathrm{~S} .9 \mathrm{H}_{2} \mathrm{O}(4.0 \mathrm{~g}, 16.7$ $\mathrm{mmol})$ in water $(10 \mathrm{~mL})$ was added to a solution of $( \pm)-1(0.20 \mathrm{~g}$, $0.51 \mathrm{mmol})$ in benzene $(20 \mathrm{~mL})$ under nitrogen. The mixture was heated under reflux for $3 \mathrm{~h}$. After cooling to room temperature, the layers were separated and the aqueous layer was extracted with benzene $(3 \times 80 \mathrm{~mL})$. The organic fractions were combined, dried $\left(\mathrm{MgSO}_{4}\right)$, and evaporated to dryness. The product was isolated as
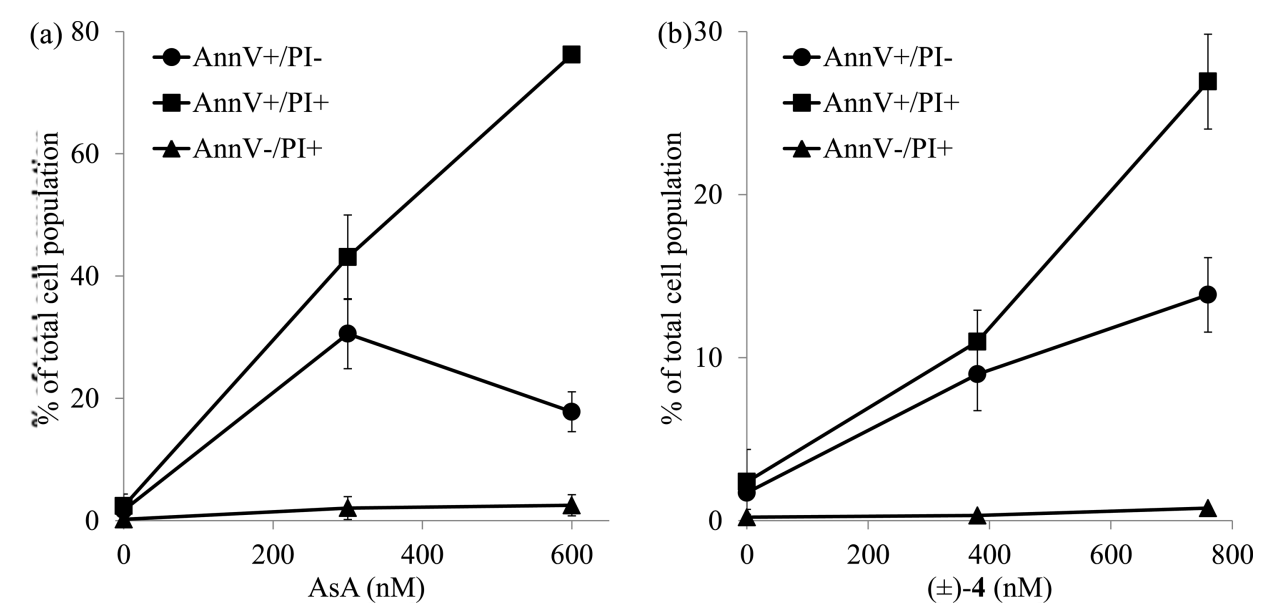

Figure 8. Induction of apoptosis in ovarian cancer cells by $( \pm)-\mathbf{1}$ and ( \pm )-4. Annexin V/PI staining of SKOV-3 cells treated with ( \pm )-1 (a) and $( \pm)-4$ (b). Values presented are mean \pm SD of cell populations from at least 2 experiments performed in duplicates. 

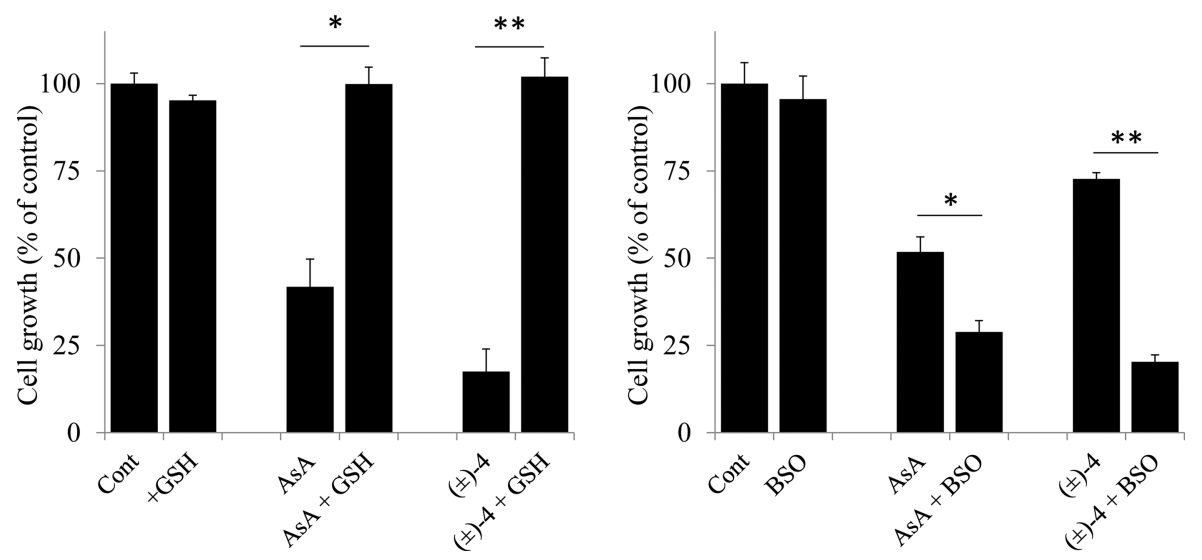

Figure 9. Effects of glutathione homeostasis modulation on the antiproliferative activities of ( \pm )-1 (AsA) and ( \pm )-4 in ovarian cancer cells. SKOV-3 cells proliferation was measured by MTT assay and expressed as a percentage of untreated cells. (a) Cells were either nontreated (cont) or treated with $( \pm)-1(500 \mathrm{nM})$ or $( \pm)-4(125 \mathrm{nM})$ in the presence and absence of $500 \mu \mathrm{M}$ glutathione ethyl ester $(\mathrm{GSH})$. (b) Cells were either nontreated (cont) or treated with $( \pm)-1$ or $( \pm)-4$ in the presence and absence of $50 \mu \mathrm{M}$ BSO. Experiments presented are representative of at least 2 experiments performed in duplicates. Values are $\pm \mathrm{SD} .{ }^{*}: p<0.05 ; * *: p<0.01$.

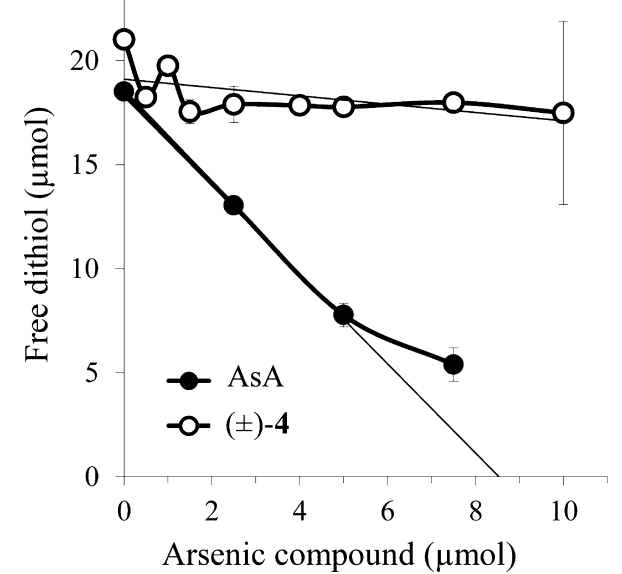

Figure 10. Diagram showing reactivities of $( \pm)-1$ and $( \pm)-4$ toward the dithiol DMP.

bright yellow, air-stable prisms following recrystallization of the evaporated residue from benzene. Yield: $0.099 \mathrm{~g}(52 \%) ; \mathrm{mp}>165{ }^{\circ} \mathrm{C}$ (decomp). Anal. Calcd $\mathrm{C}_{3} \mathrm{H}_{6} \mathrm{As}_{4} \mathrm{~S}: \mathrm{C}, 9.64 ; \mathrm{H}, 1.62 ; \mathrm{S}, 8.58$. Found: $\mathrm{C}$, 9.85; $\mathrm{H}, 1.83 ; \mathrm{S}, 8.67 .{ }^{1} \mathrm{H}$ NMR $\left(300.066 \mathrm{MHz}, \mathrm{CDCl}_{3}\right): \delta 1.29(\mathrm{~s}, 2$ $\mathrm{H}), 1.64\left(\mathrm{~d},{ }^{2} J_{\mathrm{HH}}=12.3 \mathrm{~Hz}, 2 \mathrm{H}\right), 2.10\left(\mathrm{~d},{ }^{2} \mathrm{~J}_{\mathrm{HH}}=12.3 \mathrm{~Hz}, 2 \mathrm{H}\right)$. ${ }^{13} \mathrm{C}\left\{{ }^{1} \mathrm{H}\right\}$ NMR $\left(125.697 \mathrm{MHz}, \mathrm{CDCl}_{3}\right): \delta \quad 32.5,45.3 .{ }^{1} \mathrm{H}$ NMR $\left(300.066 \mathrm{MHz}, \mathrm{C}_{6} \mathrm{D}_{6}\right): \delta 0.46(\mathrm{~s}, 2 \mathrm{H}), 1.17,1.27\left(\mathrm{AB} q,{ }^{2} J_{\mathrm{HH}}=12.3\right.$ $\mathrm{Hz}, 4 \mathrm{H}) .{ }^{13} \mathrm{C}\left\{{ }^{1} \mathrm{H}\right\}$ NMR $\left(125.697 \mathrm{MHz}, \mathrm{C}_{6} \mathrm{D}_{6}\right): \delta 32.0,45.1 .{ }^{1} \mathrm{H}$ NMR (300.066 MHz, DMSO- $\left.d_{6}\right): \delta 1.42\left(\mathrm{~d},{ }^{2} J_{\mathrm{HH}}=11.7 \mathrm{~Hz}, 2 \mathrm{H}\right)$, $1.46(\mathrm{~s}, 2 \mathrm{H}), 2.28\left(\mathrm{~d},{ }^{2} \mathrm{~J}_{\mathrm{HH}}=11.7 \mathrm{~Hz}, 2 \mathrm{H}\right)$. LR-EI MS $\left(\mathrm{CH}_{2} \mathrm{Cl}_{2}\right): \mathrm{m} / z$ $373.7\left([\mathrm{M}]^{++}\right), 389.7\left(\left[\mathrm{M}-\mathrm{CH}_{3}\right]^{++}\right), 327.7\left(\left[\mathrm{M}-\mathrm{CH}_{2} \mathrm{~S}\right]^{++}\right), 284.8([\mathrm{M}$ $\left.\left.-\mathrm{CH}_{2} \mathrm{As}\right]^{++}\right), 266.8\left([\mathrm{M}-\mathrm{AsS}]^{++}\right), 256.7\left(\left[\mathrm{M}-\mathrm{C}_{3} \mathrm{H}_{6} \mathrm{As}\right]^{+}\right), 238.8$ $\left(\left[\mathrm{M}-\mathrm{C}_{2} \mathrm{H}_{4} \mathrm{AsS}\right]^{++}\right), 224.8\left(\left[\mathrm{M}-\mathrm{C}_{3} \mathrm{H}_{6} \mathrm{AsS}\right]^{++}\right), 195.8([\mathrm{M}-$ $\left.\left.\mathrm{C}_{2} \mathrm{H}_{4} \mathrm{As}_{2}\right]^{++}\right), 181.8\left(\left[\mathrm{M}-\mathrm{C}_{3} \mathrm{H}_{6} \mathrm{As}_{2}\right]^{\bullet+}\right), 162.9\left(\left[\mathrm{M}-\mathrm{C}_{2} \mathrm{H}_{5} \mathrm{As}_{2} \mathrm{~S}\right]^{++}\right)$, $106.9\left(\left[\mathrm{M}-\mathrm{C}_{3} \mathrm{H}_{6} \mathrm{As}_{3}\right]^{++}\right)$. HR-EI MS $\left(\mathrm{CH}_{2} \mathrm{Cl}_{2}\right): \mathrm{m} / z 373.7047$ $\left(\mathrm{C}_{3} \mathrm{H}_{6} \mathrm{As}_{4} \mathrm{~S}\right.$ requires 373.7054), $358.6834\left(\mathrm{C}_{2} \mathrm{H}_{3} \mathrm{As}_{4} \mathrm{~S}\right.$ requires $358.6819)$, $327.7166\left(\mathrm{C}_{2} \mathrm{H}_{4} \mathrm{As}_{4}\right.$ requires 327.7177$), 284.7690$ $\left(\mathrm{C}_{2} \mathrm{H}_{4} \mathrm{As}_{3} \mathrm{~S}\right.$ requires 284.7682$)$. UV/vis $\left(0.0520 \mathrm{~g} \mathrm{dm}^{-3}\right.$ in $\left.\mathrm{CH}_{2} \mathrm{Cl}_{2}\right)$ : $\lambda_{\max } / \mathrm{nm} 322$ (942), 278 (6017), 249 (17 527) and 236 (16 650) $(\varepsilon /$ $\left.\mathrm{dm}^{3} \mathrm{~mol}^{-1} \mathrm{~cm}^{-1}\right)$. The same compound was isolated when a solution of the hexaiodoarsine $\mathbf{5}$ in benzene was heated with an excess of sodium sulfide under similar conditions. Yield: $53 \%$.

$\left(R *_{A s} S *_{A s} R *_{A s} R *_{A s}\right)$-Dihydro-3H-2,6-epithio $[1,2,4]$ triarsolo$[1,2-b][1,2,3,5]$ thiatriarsole, $( \pm)-3 a$, and $\left(R{ }^{*}{ }_{A s},{ }^{*}{ }_{A s} R^{*}{ }_{A s}, R^{*}{ }_{A s}\right)-$ dihydro-2,6-methano[1,2,3,5] thiatriarsolo[3,2-b][1,2,3,5]thiatriarsole, $( \pm)-3 b$. A solution of $\mathrm{Na}_{2} \mathrm{~S} .9 \mathrm{H}_{2} \mathrm{O}(34 \mathrm{mg}, 0.14 \mathrm{mmol})$ in water $(3 \mathrm{~mL})$ was added to a solution of $( \pm)-1(17.6 \mathrm{mg}, 0.045$ $\mathrm{mmol})$ in benzene $(15 \mathrm{~mL})$ under nitrogen. The mixture was stirred for ca. $15 \mathrm{~h}$ at room temperature and then the two layers were separated and the aqueous layer was extracted with benzene $(3 \times 10$ $\mathrm{mL})$. The organic fractions were combined and dried over $\mathrm{MgSO}_{4}$. The dried extract was evaporated to dryness to afford the crude product as a colorless solid, which was purified and separated into two fractions on a column of silica with use of dichloromethane $(20 \%)-n$ hexane $(80 \%)$ as eluent. The disulfide $( \pm)$-3a was isolated from the first fraction to be eluted from the column as pale yellow crystals after evaporation of the solvent and recrystallization of the residue from hot benzene. Yield: $10.4 \mathrm{mg}$ (57\%); mp >216 ${ }^{\circ} \mathrm{C}$ (decomp). ${ }^{1} \mathrm{H}$ NMR $\left(300.066 \mathrm{MHz}, \mathrm{CDCl}_{3}\right): \delta 1.57\left(\mathrm{~d},{ }^{2} J_{\mathrm{HH}}=13.5 \mathrm{~Hz}, 1 \mathrm{H}\right), 1.93\left(\mathrm{~d},{ }^{2} J_{\mathrm{HH}}\right.$ $=13.5 \mathrm{~Hz}, 1 \mathrm{H}), 2.35\left(\mathrm{~d},{ }^{2} J_{\mathrm{HH}}=12.3 \mathrm{~Hz}, 1 \mathrm{H}\right), 3.45\left(\mathrm{dd},{ }^{2} J_{\mathrm{HH}}=13.5\right.$ $\left.\mathrm{Hz},{ }^{4} J_{\mathrm{HH}}=1.8 \mathrm{~Hz}, 1 \mathrm{H}\right), 3.47\left(\mathrm{dd},{ }^{2} J_{\mathrm{HH}}=13.5 \mathrm{~Hz},{ }^{4} J_{\mathrm{HH}}=1.8 \mathrm{~Hz}, 1 \mathrm{H}\right)$, $3.97\left(\mathrm{~d},{ }^{2} J_{\mathrm{HH}}=12.3 \mathrm{~Hz}, 1 \mathrm{H}\right) .{ }^{13} \mathrm{C}\left\{{ }^{1} \mathrm{H}\right\} \operatorname{NMR}\left(125.697 \mathrm{MHz}, \mathrm{CDCl}_{3}\right)$ : $\delta$ 25.9, 27.4, 42.3. ${ }^{1} \mathrm{H}$ NMR $\left(300.066 \mathrm{MHz}, \mathrm{C}_{6} \mathrm{D}_{6}\right): \delta 0.54\left(\mathrm{~d},{ }^{2} J_{\mathrm{HH}}=\right.$ $13.5 \mathrm{~Hz}, 1 \mathrm{H}), 0.92\left(\mathrm{~d},{ }^{2} J_{\mathrm{HH}}=13.5 \mathrm{~Hz}, 1 \mathrm{H}\right), 1.54\left(\mathrm{~d},{ }^{2} J_{\mathrm{HH}}=12.3 \mathrm{~Hz}\right.$, $1 \mathrm{H}), 2.68\left(\mathrm{dd},{ }^{2} J_{\mathrm{HH}}=13.5 \mathrm{~Hz},{ }^{4} J_{\mathrm{HH}}=1.8 \mathrm{~Hz}, 1 \mathrm{H}\right), 2.97\left(\mathrm{dd},{ }^{2} J_{\mathrm{HH}}=\right.$ $\left.13.5 \mathrm{~Hz},{ }^{4} J_{\mathrm{HH}}=1.8 \mathrm{~Hz}, 1 \mathrm{H}\right), 3.12\left(\mathrm{~d},{ }^{2} J_{\mathrm{HH}}=12.3 \mathrm{~Hz}, 1 \mathrm{H}\right) .{ }^{13} \mathrm{C}\left\{{ }^{1} \mathrm{H}\right\}$ NMR (125.697 MHz, $\left.\mathrm{C}_{6} \mathrm{D}_{6}\right): \delta 25.1,26.6$, 41.6. LR-EI MS: $m / z 405.7$ $\left([\mathrm{M}]^{++}\right), 390.7\left(\left[\mathrm{M}-\mathrm{CH}_{3}\right]^{++}\right), 373.7\left([\mathrm{M}-\mathrm{S}]^{++}\right), 359.7([\mathrm{M}-$ $\left.\left.\mathrm{CH}_{2} \mathrm{~S}\right]^{++}\right), 327.7\left(\left[\mathrm{M}-\mathrm{CH}_{2} \mathrm{~S}_{2}\right]^{++}\right), 298.8\left([\mathrm{M}-\mathrm{AsS}]^{++}\right), 284.8([\mathrm{M}$ $\left.\left.-\mathrm{CH}_{2} \mathrm{AsS}\right]^{+}\right), 270.7\left(\left[\mathrm{M}-\mathrm{C}_{2} \mathrm{H}_{4} \mathrm{AsS}\right]^{++}\right), 256.7\left(\left[\mathrm{M}-\mathrm{C}_{3} \mathrm{H}_{6} \mathrm{AsS}\right]^{+}\right)$, $238.8\left(\left[\mathrm{M}-\mathrm{C}_{2} \mathrm{H}_{4} \mathrm{AsS}_{2}\right]^{++}\right), 224.8\left(\left[\mathrm{M}-\mathrm{C}_{3} \mathrm{H}_{6} \mathrm{AsS}_{2}\right]^{++}\right), 195.8([\mathrm{M}-$ $\left.\left.\mathrm{C}_{2} \mathrm{H}_{4} \mathrm{As}_{2} \mathrm{~S}\right]^{++}\right), 181.8\left(\left[\mathrm{M}-\mathrm{C}_{3} \mathrm{H}_{6} \mathrm{As}_{2} \mathrm{~S}\right]^{++}\right), 162.9\left(\left[\mathrm{M}-\mathrm{C}_{2} \mathrm{H}_{5} \mathrm{As}_{2} \mathrm{~S}_{2}\right]^{++}\right)$, $149.0\left(\left[\mathrm{M}-\mathrm{C}_{3} \mathrm{H}_{6} \mathrm{As}_{2} \mathrm{~S}_{2}\right]^{++}\right), 106.9\left(\left[\mathrm{M}-\mathrm{C}_{3} \mathrm{H}_{6} \mathrm{As}_{3} \mathrm{~S}\right]^{++}\right)$. HR-EI MS $\left(\mathrm{CH}_{2} \mathrm{Cl}_{2}\right): m / z 405.6777\left(\mathrm{C}_{3} \mathrm{H}_{6} \mathrm{As}_{4} \mathrm{~S}_{2}\right.$ requires 405.6775), 373.7064 $\left(\mathrm{C}_{3} \mathrm{H}_{6} \mathrm{As}_{4} \mathrm{~S}\right.$ requires 373.7054), $359.6906\left(\mathrm{C}_{2} \mathrm{H}_{4} \mathrm{As}_{4} \mathrm{~S}\right.$ requires 359.6898), $316.7395\left(\mathrm{C}_{2} \mathrm{H}_{4} \mathrm{As}_{3} \mathrm{~S}_{2}\right.$ requires 316.7402$)$. UV/vis $\left(0.0417 \mathrm{~g} \mathrm{dm}^{-3}\right.$ in $\left.\mathrm{CH}_{2} \mathrm{Cl}_{2}\right): \lambda_{\max } / \mathrm{nm} 309$ (2229), 280 (3942), 256 (6113) and $232(10405)\left(\varepsilon / \mathrm{dm}^{3} \mathrm{~mol}^{-1} \mathrm{~cm}^{-1}\right)$. The diastereomer $( \pm)-\mathbf{3 b}$ was similarly isolated and purified from the second fraction to be eluted from the column: colorless crystals $(3.8 \mathrm{mg}, 21 \%)$; $\mathrm{mp}>162$ ${ }^{\circ} \mathrm{C} .{ }^{1} \mathrm{H}$ NMR $\left(300.066 \mathrm{MHz}, \mathrm{CDCl}_{3}\right): \delta 1.49(\mathrm{~s}, 2 \mathrm{H}), 2.10\left(\mathrm{~d},{ }^{2} J_{\mathrm{HH}}=\right.$ $12.3 \mathrm{~Hz}, 2 \mathrm{H}), 3.53\left(\mathrm{~d},{ }^{2} J_{\mathrm{HH}}=12.3 \mathrm{~Hz}, 2 \mathrm{H}\right) .{ }^{13} \mathrm{C}\left\{{ }^{1} \mathrm{H}\right\} \mathrm{NMR}(125.697$ $\left.\mathrm{MHz}, \mathrm{CDCl}_{3}\right): \delta 8.1,38.9 .{ }^{1} \mathrm{H} \mathrm{NMR}\left(300.066 \mathrm{MHz}, \mathrm{C}_{6} \mathrm{D}_{6}\right): \delta 0.61(\mathrm{~s}$, $2 \mathrm{H}), 1.36\left(\mathrm{~d},{ }^{2} \mathrm{~J}_{\mathrm{HH}}=12.3 \mathrm{~Hz}, 2 \mathrm{H}\right), 2.84\left(\mathrm{~d},{ }^{2} J_{\mathrm{HH}}=12.3 \mathrm{~Hz}, 2 \mathrm{H}\right)$. ${ }^{13} \mathrm{C}\left\{{ }^{1} \mathrm{H}\right\}$ NMR $\left(125.697 \mathrm{MHz}, \mathrm{C}_{6} \mathrm{D}_{6}\right): \delta 7.2,38.4$. LR-EI MS $\left(\mathrm{CH}_{2} \mathrm{Cl}_{2}\right): m / z 405.7\left([\mathrm{M}]^{++}\right), 390.7\left(\left[\mathrm{M}-\mathrm{CH}_{3}\right]^{+}\right), 373.7([\mathrm{M}-$ $\left.\mathrm{S}]^{++}\right), 359.7\left(\left[\mathrm{M}-\mathrm{CH}_{2} \mathrm{~S}\right]^{++}\right), 327.7\left(\left[\mathrm{M}-\mathrm{CH}_{2} \mathrm{~S}_{2}\right]^{++}\right), 298.8([\mathrm{M}-$ $\left.\mathrm{AsS}]^{++}\right), 284.8\left(\left[\mathrm{M}-\mathrm{CH}_{2} \mathrm{AsS}\right]^{++}\right), 270.7\left(\left[\mathrm{M}-\mathrm{C}_{2} \mathrm{H}_{4} \mathrm{AsS}\right]^{++}\right), 256.7$ $\left(\left[\mathrm{M}-\mathrm{C}_{3} \mathrm{H}_{6} \mathrm{AsS}\right]^{++}\right), 238.8\left(\left[\mathrm{M}-\mathrm{C}_{2} \mathrm{H}_{4} \mathrm{AsS}_{2}\right]^{++}\right), 224.8([\mathrm{M}-$ $\left.\left.\mathrm{C}_{3} \mathrm{H}_{6} \mathrm{AsS}_{2}\right]^{++}\right), 195.8\left(\left[\mathrm{M}-\mathrm{C}_{2} \mathrm{H}_{4} \mathrm{As}_{2} \mathrm{~S}\right]^{++}\right), 181.8\left(\left[\mathrm{M}-\mathrm{C}_{3} \mathrm{H}_{6} \mathrm{As}_{2} \mathrm{~S}\right]^{++}\right)$, $162.9\left(\left[\mathrm{M}-\mathrm{C}_{2} \mathrm{H}_{5} \mathrm{As}_{2} \mathrm{~S}_{2}\right]^{++}\right), 149.0\left(\left[\mathrm{M}-\mathrm{C}_{3} \mathrm{H}_{6} \mathrm{As}_{2} \mathrm{~S}_{2}\right]^{++}\right), 106.9([\mathrm{M}-$ $\left.\left.\mathrm{C}_{3} \mathrm{H}_{6} \mathrm{As}_{3} \mathrm{~S}\right]^{++}\right)$. HR-EI MS $\left(\mathrm{CH}_{2} \mathrm{Cl}_{2}\right): m / z \quad 405.6776\left(\mathrm{C}_{3} \mathrm{H}_{6} \mathrm{As}_{4} \mathrm{~S}_{2}\right.$ requires 405.6775), $390.6545\left(\mathrm{C}_{2} \mathrm{H}_{3} \mathrm{As}_{4} \mathrm{~S}_{2}\right.$ requires 390.6540), 
$373.7037\left(\mathrm{C}_{3} \mathrm{H}_{6} \mathrm{As}_{4} \mathrm{~S}\right.$ requires 373.7054), $359.6887 \quad\left(\mathrm{C}_{2} \mathrm{H}_{4} \mathrm{As}_{4} \mathrm{~S}\right.$ requires 359.6898), $316.7390\left(\mathrm{C}_{2} \mathrm{H}_{4} \mathrm{As}_{3} \mathrm{~S}_{2}\right.$ requires 316.7402$)$. UV/ vis $\left(0.0500 \mathrm{~g} \mathrm{dm}^{-3}\right.$ in $\left.\mathrm{CH}_{2} \mathrm{Cl}_{2}\right): \lambda_{\max } / \mathrm{nm} 315$ (1680), 280 (2866), 248 (5228) and $231(8110)\left(\varepsilon / \mathrm{dm}^{3} \mathrm{~mol}^{-1} \mathrm{~cm}^{-1}\right)$.

X-ray Crystallography. Single-crystal X-ray diffraction data for $( \pm)-4,( \pm)-\mathbf{3 a}$, and $( \pm)-\mathbf{3 b}$ were collected on a Nonius Kappa CCD diffractometer with use of graphite-monochromated Mo $\mathrm{K} \alpha$ radiation ( $\lambda=0.71073 \AA$ ). The structures were solved by direct methods using SIR92 and refined using CRYSTALS and RAELS06. ${ }^{12,27,28}$

Compound ( \pm )-4. $\mathrm{C}_{3} \mathrm{H}_{6} \mathrm{As}_{4} \mathrm{~S}, \mathrm{M}=373.83$, yellow needle, $0.53 \times$ $0.14 \times 0.10 \mathrm{~mm}$, monoclinic, space group $\mathrm{C} 2 / \mathrm{c}$. Cell parameters: $a=$ 9.7809(2) $\AA, b=9.6439(3) \AA, c=8.6189(2) \AA, \beta=101.2818(17)^{\circ}, V$ $=797.28(4) \AA^{3}, Z=4, D_{x}=3.114 \mathrm{~g} \mathrm{~cm}^{-3}, \mathrm{~F}(000)=688 . \mu(\mathrm{Mo} \mathrm{K \alpha})=$ $16.78 \mathrm{~mm}^{-1}, T=200 \mathrm{~K} .10278$ measured reflections, 1171 independent reflections, $R=0.027$ for 1080 reflections with $I>$ $3 \sigma(I), R_{w}=0.035,49$ parameters.

Compound ( \pm - $-3 a$. $\mathrm{C}_{3} \mathrm{H}_{6} \mathrm{As}_{4} \mathrm{~S}_{2}, \mathrm{M}=405.90$, monoclinic, pale yellow plate, $0.23 \times 0.15 \times 0.06 \mathrm{~mm}$, monoclinic, space group $P 2_{1} / n$. Cell parameters: $a=6.4860(1) \AA, b=11.3785(2) \AA, c=12.2027(2) \AA$, $\beta=95.4032(10)^{\circ}, V=896.57(3) \AA^{3}, Z=4, D_{x}=3.010 \mathrm{~g} \mathrm{~cm}^{-3}, \mathrm{~F}(000)$ $=752 . \mu($ Mo $\mathrm{K} \alpha)=15.18 \mathrm{~mm}^{-1}, T=200 \mathrm{~K} .24066$ measured reflections, 2612 independent reflections, $\mathrm{R}=0.030$ for 2261 reflections with $I>3 \sigma(I), R_{w}=0.037,79$ parameters.

Compound ( \pm )-3b. $\mathrm{C}_{3} \mathrm{H}_{6} \mathrm{As}_{4} \mathrm{~S}_{2}, \mathrm{M}=405.90$, colorless octahedron, $0.19 \times 0.19 \times 0.16 \mathrm{~mm}$, tetragonal, space group $\mathrm{P}_{3}$. Cell parameters: $a=7.0408(2) \AA, c=18.2503(5) \AA, V=904.72(4) \AA^{3}, Z=4, D_{x}=$ $2.980 \mathrm{~g} \mathrm{~cm}^{-3}, \mathrm{~F}(000)=752 . \mu($ Mo K $\alpha)=15.02 \mathrm{~mm}^{-1}, T=200 \mathrm{~K}$. 11676 measured reflections, 2637 independent reflections, $R=0.024$ for 2596 reflections with $I>3 \sigma(I), R_{w}=0.032,72$ parameters.

Crystal data are available from the Cambridge Crystallographic Database as file numbers CCDC 1005782-1005784.

Computational Procedures. The calculations of the UV/vis spectra were performed using the GAUSSIAN09 suite of programs. ${ }^{29}$ Geometry optimizations were carried out using the B3LYP functional with the $6-311+\mathrm{G}(3 d f, 2 p d)$ basis set. ${ }^{30,31}$ The nature of the optimized structures was determined by carrying out frequency calculations that showed that all of the optimized structures are minima on the potential energy surface. The vertical absorption spectra of all of the selected systems were obtained using time-dependent density functional theory (TDDFT) with the B3LYP functional with the same large triple- $\zeta$ basis set, $6-311+\mathrm{G}(3 d f, 2 p d)$, at the optimized ground-state geometries. $^{32-35}$ This theory combination, TDDFT(B3LYP) with $6-311+G(3 d f, 2 p d)$, was previously shown to provide reliable results for the parent cage $( \pm)-1 .^{8}$

Cell Proliferation Assay. Except otherwise mentioned, all the reagents and chemicals were from Sigma (St Louis, MO). The $1 \mathrm{M}$ arsenic(III) oxide solution was prepared by dissolving arsenic(III) oxide (Sigma, St. Louis, MO) in $3 \mathrm{M}$ aqueous sodium hydroxide and diluting the solution 10-fold with deoxygenated water, followed by adjusting the $\mathrm{pH}$ to 7.0 with hydrochloric acid; the neutral solution was stored at $4{ }^{\circ} \mathrm{C}$ in an airtight container. The $10 \mathrm{mM}$ solutions of $( \pm)-1$ and $( \pm)-4$ were prepared by dissolving the crystalline solids in dimethyl sulfoxide (DMSO).

Except where otherwise indicated, cells were purchased from ATCC (Bethesda, VA) and culture media, serum, antibiotics and supplements were obtained from Invitrogen (Mulgrave, VIC, Australia). All cultures were supplemented with $2 \mathrm{mM} \mathrm{L}$-glutamine, and 10 units $/ \mathrm{mL}$ penicillin $+10 \mu \mathrm{g} / \mathrm{mL}$ streptomycin. All cell lines tested negative for contamination with MycoAlert (Lonza, Basel, Switzerland) and were maintained in a controlled environment of $5 \% \mathrm{CO}_{2}$ and $95 \%$ relative humidity at $37^{\circ} \mathrm{C}$. Cell culture plastic-ware was purchased from Nunc (Roskilde, Denmark). The NB4 cells (human acute promyelocytic leukemia) were obtained from Shane Supple (Kanematsu Laboratories, Royal Prince Alfred Hospital, Sydney, Australia) and were seeded at a density of $4 \times 10^{3}$ cells per well into 96-well plates. The SKOV-3 (human ovarian adenocarcinoma), MDA-MB-231 (human metastatic breast adenocarcinoma), MRC 5 (human normal lung fibroblast), HOSE 17.1 (human normal ovarian surface epithelium) and MCF 10A (human noncancerous breast epithelium) cells were seeded at a density of $4 \times 10^{3}, 4 \times 10^{3}, 4 \times 10^{4}, 2 \times 10^{4}, 2 \times 10^{4}$ cells per well into 96-well plates, respectively. The 2008 cells (human ovarian carcinoma) were obtained from Sheri Nixdorf (University of New South Wales, Adult Cancer Program, Sydney, Australia) and were plated at a density of $5 \times 10^{3}$ cells per well into 96-well plates. SKOV-3, MDA MB 231 and NB4 cells were cultured in RPMI medium $10 \%$ fetal + calf serum (FBS). The ovarian 2008 cells were cultured in DMEM medium $+20 \%$ FBS. MRC 5 cells were cultured in MEM medium supplemented with $1 \mathrm{mM}$ sodium pyruvate, $1 \%$ nonessential amino acids (NEAA), $1.5 \mathrm{~g} /$ L sodium bicarbonate. HOSE 17.1 cells were grown in 1:1 Medium 199:MCDB 105. MCF 10A cells were grown in 1:1 DMEM:F12 supplemented with epidermal growth factor $(20 \mu \mathrm{g} / \mathrm{mL})$, hydrocortisone $(1 \mathrm{mg} / \mathrm{mL})$, insulin $(4 \mathrm{mg} / \mathrm{mL})$ and horse serum $(10 \%)$. Where indicated, NB4 cells were differentiated with $1 \mu \mathrm{M}$ all-trans retinoic acid (ATRA) for $72 \mathrm{~h} .^{21}$ Adherent cells were allowed to adhere overnight. The cells were then cultured for $72 \mathrm{~h}$ in media containing or not various concentrations of $( \pm)-1$ and $( \pm)-4$. Viable cells were determined by incubation with the tetrazolium salt MTT (Sigma, St. Louis, MO), which is metabolized by viable cells to form insoluble purple formazan crystals. ${ }^{36}$ DMSO was added to lyze cells and the contents of the wells were homogenized and the absorbance measured at $550 \mathrm{~nm}$. Cell number in the untreated control was normalized as $100 \%$, and the viable cell number for each treatment was expressed as a percentage of the control.

PML Sumoylation, Degradation. The MEF $\mathrm{pml}^{-/-}$cell line stably expressing PML III isoform (MEF-PML) was cultured in DMEM medium supplemented with $10 \%$ FBS. ${ }^{37}$ MEF-PML cells were seeded at a density of $5 \times 10^{5}$ cells per well into 6-well plates. Adherent cells were allowed to adhere overnight. For sumoylation analysis, the cells were treated for $1 \mathrm{~h}$ with either 1 or $0.5 \mathrm{uM}$ aq. arsenic(III) oxide (Sigma, St. Louis, MO), AsA, or monosulfide ( \pm )-4 in DMSO. For degradation analysis, the cells were treated with $3 \mathrm{uM}$ aqueous $\mathrm{As}_{2} \mathrm{O}_{3}, 10 \mathrm{nM}$ AsA, or $5 \mathrm{nM}( \pm)-4$ in DMSO for $9 \mathrm{~h}$. The cells were rinsed twice before adding Leammli buffer for whole cell lysates analysis. Denaturated samples $\left(95^{\circ} \mathrm{C}\right.$ for $\left.10 \mathrm{~min}\right)$ were run on a gradient SDS-PAGE $4-10 \%$ gel (BioRad). The gel was then transferred onto a nitrocellulose membrane (GE) (100 V for $3 \mathrm{~h})$ and the membrane was blocked with $5 \%$ nonfat milk before adding the primary antibody (overnight at $4{ }^{\circ} \mathrm{C}$ ). After incubation with an HRPconjugated secondary antibody (Merck Millipore), ECL (Pierce) was used for chemiluminescence detection. The anti-HA was used at a dilution of 1:2 000 (Covance). The loading controls used were antiGAPDH at a dilution of 1:5000 and antiactin at a dilution of 1:10 000 (Sigma). Quantifications were performed using Vilber Lourmat technology.

PML Recruitment in Nuclear Bodies. The MEF-PML cells were seeded on $10 \mathrm{~mm}$ diameter coverslips into a 6-well plate for $24 \mathrm{~h}$ at 37 ${ }^{\circ} \mathrm{C}$ in a $5 \% \mathrm{CO}_{2} / 95 \%$ air atmosphere. The cells were then treated with either $2 \mu \mathrm{M}$ aqueous $\mathrm{As}_{2} \mathrm{O}_{3}$ or $20 \mathrm{nM}$ AsA or $10 \mathrm{nM}( \pm)-4$ in DMSO for $1 \mathrm{~h}$. The cells were rinsed with PBS, then fixed with $4 \%$ formaldehyde (Sigma) for $15 \mathrm{~min}$ and permeabilized with $0.5 \% \mathrm{X}$ Triton 100 TBS for $15 \mathrm{~min}$. The immunofluorescence procedure used is described in ref 37. Anti-HA was used at a dilution of 1:1 000 (Covance), and the 488-secondary antibody was used at a dilution of 1:1 000 (Jackson ImmunoReseach). Fluorescent images were acquired on an Axio Observer.ZI microscope with an Apotome camera with a 63x/1.40-numerical-aperture (NA). Plan-Apochromat. Images were acquired with AxioVision software (Carl Zeiss, Germany).

Induction of Apotosis by $( \pm)-1$ and $( \pm)-4$. Fluorescent activated cell sorting (FACS) analysis was performed on a FACS Canto II (Becton Dickinson, Franklin Lakes, NJ) flow cytometer. 10,000 events were recorded for each sample. Debris was excluded by gating out events with distinctively low FSC (forward scatter) and SSC (side scatter) measurements. Apoptosis was detected using flow cytometry with Annexin-V and propridium iodide (PI) staining. ${ }^{38}$ Cells were treated for $24 \mathrm{~h}$ with $( \pm)-1$ and $( \pm)-4$ and then stained with Annexin-V (Annexin-V-FLUOS, Roche, Mannheim, Germany) and PI. Annexin-V was excited at $488 \mathrm{~nm}$ and the data were collected at the FITC channel $(518 \mathrm{~nm})$; PI was excited at $488-540 \mathrm{~nm}$ and the data were collected at the PI channel $(617 \mathrm{~nm})$. 
Binding of $( \pm)-1$ and $( \pm)-4$ to 2,3-Dimercapto-1-propanol (DMP). With use of the arsenic(III) titration technique, it was demonstrated that $( \pm)-1$ binds with DMP.,18 A comparison of the reactivities of the parent $( \pm)-1$ and the monosulfide $( \pm)-4$ toward DMP has been made. Thus, increasing concentrations of $( \pm)-1$ or ( \pm )-4 (suspended in $0.14 \mathrm{M} \mathrm{NaCl}, 20 \mathrm{mM}$ Hepes, $20 \mathrm{mM}$ glycine, and $1 \mathrm{mM}$ EDTA at $\mathrm{pH} 7.0)$ were mixed with a specific excess of DMP and each solution was treated with an excess of 5,5' -dithiobis(2nitrobenzoic acid) (DTNB). The excess DMP in each solution was then determined by measuring the intensity of the absorption for the bright yellow thionitrobenzoic acid derivative of DMP at $412 \mathrm{nM}$. As the quantity of $( \pm)-1$ increased, the amount of free DMP detected by the DTNB decreased, thus demonstrating the binding of $( \pm)-\mathbf{1}$ to the DMP. No significant binding of ( \pm ) -4 to the DMP was detected.

\section{ASSOCIATED CONTENT}

\section{S Supporting Information}

Full details and analysis of the computational UV absorption spectra and bonding in ( \pm )-4, ( \pm )-3a, and ( \pm ) $-3 \mathbf{b}$. This material is available free of charge via the Internet at http:// pubs.acs.org.

\section{AUTHOR INFORMATION}

\section{Corresponding Authors}

*(G.S.) Phone: +61 26125 3043. Fax: +61 26125 0760. Email: geoff.salem@anu.edu.au.

*(S.B.W.) Phone: +6126125 4236. Fax: +61 26125 0750. Email: bruce.wild@anu.edu.au.

\section{Notes}

The authors declare no competing financial interest.

\section{ACKNOWLEDGMENTS}

The theoretical contribution was supported by the Australian Research Council (ARC) and the Australian National Computational Infrastructure. M.L.C. gratefully acknowledges the award of an ARC Future Fellowship. The biological work was supported by a program grant from the Cancer Council NSW and a Faculty Research Grant from the Faculty of Medicine (University of New South Wales, Australia); S.B. gratefully acknowledges the receipt of a grant from the European Research Council.

\section{REFERENCES}

(1) Mancini, I.; Guella, G.; Frostin, M.; Hnawia, E.; Laurent, D.; Debitus, C.; Pietra, F. Chem.-Eur. J. 2006, 12, 8989.

(2) Lu, D.; Rae, A. D.; Salem, G.; Weir, M. L.; Willis, A. C.; Wild, S. B. Organometallics 2010, 29, 32.

(3) Tahtinen, P.; Saielli, G.; Guella, G.; Mancini, I.; Bagno, A. Chem.-Eur. J. 2008, 14, 10445.

(4) Guella, G.; Mancini, I.; Mariotto, G.; Rossi, B.; Viliani, G. Phys. Chem. Chem. Phys. 2009, 11, 2420.

(5) Bagno, A. J. Phys. Org. Chem. 2010, 23, 1016.

(6) Francesconi, K. A.; Keuhnelt, D. In Environmental Chemistry of Arsenic; Frankenberger, W. T., Jr., Eds.; Marcel Dekker: New York, 2002; pp 51-116.

(7) Reimer, K. J.; Koch, I.; Cullen, W. R. Organoarsenicals. Distribution and transformation in the environment. In Organometallics in Environment and Toxicology; Sigel, A., Sigel, H., Sigel, R. K. O., Eds.; The Royal Society of Chemistry: Cambridge, 2010; Vol. 7, pp 165-229.

(8) Arulmozhiraja, S.; Coote, M. L.; Lu, D.; Salem, G.; Wild, S. B. J. Phys. Chem. A 2011, 115, 4530.

(9) Lu, D.; Coote, M. L.; Ho, J.; Kilah, N. L.; Lin, C.; Salem, G.; Weir, M. L.; Willis, A. C.; Wild, S. B.; Dilda, P. J. Organometallics 2012, 31, 1808.
(10) Gugger, P.; Willis, A. C.; Wild, S. B. J. Chem. Soc., Chem. Commun. 1990, 1169.

(11) Dilda, P. J.; Hogg, P. J. Cancer Treat. Rev. 2007, 33, 542.

(12) (a) Rae, A. D. Acta Crystallogr. 1975, A30, 560. (b) Rae, A. D. RAELSO6; Australian National University: Canberra, 2006.

(13) Bonazzi, P.; Bindi, L. Z. Kristallogr. 2008, 223, 132.

(14) Mullen, D. J. E.; Nowacki, W. Z. Kristallogr. 1972, 136, 48.

(15) Bindi, L.; Popova, V. I.; Bonazzi, P. Can. Mineral. 2003, 41, 1463.

(16) Mandegary, A.; Mehrabani, M. DARU J. Pharmaceutical Sci. 2010, 18, 303.

(17) Jeanne, M.; Lallemand-Breitenbach, V.; Ferhi, O.; Koken, M.; Le Bras, M.; Duffort, S.; Peres, L.; Berthier, C.; Soilihi, H.; Raught, B.; de Thé, H. Cancer Cell 2010, 18, 88.

(18) Dilda, P. J.; Joshi, S.; Lu, D.; Decollogne, S.; Allen, J. D.; Heinzelmann-Schwarz, V.; Salem, G.; Wild, S. B. Eur. J. Cancer 2012, 48, 250.

(19) Dilda, P. J.; Don, A. S.; Tanabe, K. M.; Higgins, V. J.; Allen, J. D.; Dawes, I. W.; Hogg, P. J. J. Natl. Cancer Inst. 2005, 97 (20), 1539.

(20) Dilda, P. J.; Decollogne, S.; Weerakoon, L.; Norris, M. D.; Haber, M.; Allen, J. D.; Hogg, P. J. J. Med. Chem. 2009, 52, 6209.

(21) Dilda, P. J.; Perrone, G. G.; Philp, A.; Lock, R. B.; Dawes, I. W.; Hogg, P. J. Int. J. Biochem. Cell Biol. 2008, 40, 1016.

(22) Jiang, X.; Chen, C.; Liu, Y.; Zhang, P.; Zhang, Z. Mutation Res./ Genet. Toxicol. Environ. Mutagenesis 2014, 770, 35.

(23) Donoghue, N.; Yam, P. T.; Jiang, X. M.; Hogg, P. J. Protein Sci. 2000, 9, 2436.

(24) Don, A. S.; Kisker, O.; Dilda, P.; Donoghue, N.; Zhao, X.; Decollogne, S.; Creighton, B.; Flynn, E.; Folkman, J.; Hogg, P. J. Cancer Cell 2003, 3, 497.

(25) Park, D.; Chiu, J.; Perrone, G. G.; Dilda, P. J.; Hogg, P. J. Cancer Cell Int. 2012, 12, 11.

(26) Amerago, W. F.; Chai, C. L. L. Purification of Laboratory Chemicals, $5^{\text {th }}$ ed.; Butterworth-Heinemann: Amsterdam, 2003.

(27) Altomare, A.; Cascarano, G.; Giacovazzo, C.; Guagliardi, A.; Burla, M. C.; Polidori, G.; Camalli, M. J. Appl. Crystallogr. 1994, 27, 435 .

(28) Betteridge, P. W.; Carruthers, J. R.; Cooper, R. I.; Prout, K.; Watkin, D. J. J. Appl. Crystallogr. 2003, 36, 1487.

(29) Frisch, M. J.; Trucks, G. W.; Schlegel, H. B.; Scuseria, G. E.; Robb, M. A.; Cheeseman, J. R.; Scalmani, G.; Barone, V.; Mennucci, B.; Petersson, G. A.; Nakatsuji, H.; Caricato, M.; Li, X.; Hratchian, H. P.; Izmaylov, A. F.; Bloino, J.; Zheng, G.; Sonnenberg, J. L.; Hada, M.; Ehara, M.; Toyota, K.; Fukuda, R.; Hasegawa, J.; Ishida, M.; Nakajima, T.; Honda, Y.; Kitao, O.; Nakai, H.; Vreven, T.; Montgomery, Jr., J. A.;Peralta, J. E.; Ogliaro, F.; Bearpark, M.; Heyd, J. J.; Brothers, E.; Kudin, K. N.; Staroverov, V. N.; Keith, T.; Kobayashi, R.; Normand, J.; Raghavachari, K.; Rendell, A.; Burant, J. C.; Iyengar, S. S.; Tomasi, J.; Cossi, M.; Rega, N.; Millam, J. M.; Klene, M.; Knox, J. E.; Cross, J. B.; Bakken, V.; Adamo, C.; Jaramillo, J.; Gomperts, R; Stratmann, R. E.; Yazyev, O.; Austin, A. J.; Cammi, R.; Pomelli, C.; Ochterski, J. W.; Martin, R. L.; Morokuma, K.; Zakrzewski, V. G.; Voth, G. A.; Salvador, P.; Dannenberg, J. J.; Dapprich, S.; Daniels, A. D.; Farkas, O.; Foresman, J. B.; Ortiz, J. V.; Cioslowski, J.; Fox, D. J. Gaussian 09, Revision B.01; Gaussian: Wallingford, CT, 2010.

(30) Becke, A. J. Chem. Phys. 1993, 98, 5648.

(31) Lee, C.; Yang, W.; Parr, R. G. Phys. Rev. B 1998, 37, 785.

(32) Stratmann, R. E.; Scuseria, G. E.; Frisch, M. J. J. Chem. Phys. 1998, 109, 8218.

(33) Bauernschmitt, R; Ahlrichs, R. Chem. . Phys. Lett. 1996, 256, 454.

(34) Casida, M. E.; Jamorski, C.; Casida, K. C.; Salahub, D. R. J. Chem. Phys. 1998, 108, 4439.

(35) Dreuw, A.; Head-Gordon, M. Chem. Rev. 2005, 105, 4009.

(36) Mosmann, T. J. Immunol. Methods 1983, 65, 55.

(37) Sahin, U.; Ferhi, O.; Jeanne, M.; Benhenda, S.; Berthier, C.; Jollivet, F.; Niwa-Kawakita, M.; Faklaris, O.; Setterblad, N.; de Thé, H.; Lallemand-Breitenbach, V. J. Cell Biol. 2014, 204, 931. 
(38) Vermes, I.; Haanen, C.; Steffens-Nakken, H.; Reutellingsperger, C. J. Immunol. Methods 1995, 184, 39. 